\title{
Metasediments Covering Ophiolites in the HP Internal Belt of the Western Alps: Review of Tectono-Stratigraphic Successions and Constraints for the Alpine Evolution
}

\author{
Paola Tartarotti ${ }^{1, *} \mathbb{\infty}$, Silvana Martin ${ }^{2} \mathbb{D}$, Andrea Festa ${ }^{3}\left(\mathbb{D}\right.$ and Gianni Balestro ${ }^{3}$ \\ 1 Dipartimento di Scienze della Terra “Ardito Desio", Università degli Studi di Milano, Via Mangiagalli 34, \\ 20133 Milano, Italy \\ 2 Dipartimento di Geoscienze, Università degli Studi di Padova, Via G. Gradenigo 6, 35131 Padova, Italy; \\ silvana.martin@unipd.it \\ 3 Dipartimento di Scienze della Terra, Università di Torino, Via Valperga Caluso 35, 10125 Torino, Italy; \\ andrea.festa@unito.it (A.F.); gianni.balestro@unito.it (G.B.) \\ * Correspondence: paola.tartarotti@unimi.it
}

check for

updates

Citation: Tartarotti, P.; Martin, S.; Festa, A.; Balestro, G. Metasediments Covering Ophiolites in the HP Internal Belt of the Western Alps: Review of Tectono-Stratigraphic Successions and Constraints for the Alpine Evolution. Minerals 2021, 11, 411. https://doi.org/10.3390/min 11040411

Academic Editor: Wenjiao Xiao

Received: 5 March 2021

Accepted: 6 April 2021

Published: 14 April 2021

Publisher's Note: MDPI stays neutral with regard to jurisdictional claims in published maps and institutional affiliations.

Copyright: (c) 2021 by the authors. Licensee MDPI, Basel, Switzerland. This article is an open access article distributed under the terms and conditions of the Creative Commons Attribution (CC BY) license (https:/ / creativecommons.org/licenses/by/ $4.0 /)$.

\begin{abstract}
Ophiolites of the Alpine belt derive from the closure of the Mesozoic Tethys Ocean that was interposed between the palaeo-Europe and palaeo-Adria continental plates. The Alpine orogeny has intensely reworked the oceanic rocks into metaophiolites with various metamorphic imprints. In the Western Alps, metaophiolites and continental-derived units are distributed within two paired bands: An inner band where Alpine subduction-related high-pressure (HP) metamorphism is preserved, and an outer band where blueschist to greenschist facies recrystallisation due to the decompression path prevails. The metaophiolites of the inner band are hugely important not just because they provide records of the prograde tectonic and metamorphic evolution of the Western Alps, but also because they retain the signature of the intra-oceanic tectono-sedimentary evolution. Lithostratigraphic and petrographic criteria applied to metasediments associated with HP metaophiolites reveal the occurrence of distinct tectono-stratigraphic successions including quartzites with marbles, chaotic rock units, and layered calc schists. These successions, although sliced, deformed, and superposed in complex ways during the orogenic stage, preserve remnants of their primary depositional setting constraining the pre-orogenic evolution of the Jurassic Tethys Ocean.
\end{abstract}

Keywords: Western Alps; ophiolite; metasediments; calc schist; Tethyan Ocean

\section{Introduction}

Ophiolites are a major component of the Alpine-Himalayan orogenic belt [1-3] (Figure 1A). They represent tectonic slices deriving from the oceanic lithosphere of the Jurassic Tethys Ocean and have thus been named Tethyan ophiolites [4,5]). Differently from other well known ophiolites of the Mediterranean area, such as the Troodos ophiolite in Cyprus [6,7], the metaophiolites of the Alpine belt have been intensely deformed and metamorphosed; they presently occur as tectonic slivers pinched between the palaeo-Europe and palaeoAdria continental domains [8-10]. The Alpine orogenic cycle has deeply reworked the original characters of the primary oceanic lithosphere. Consequently, the internal structural and stratigraphic features of the Alpine metaophiolites are not comparable with those of the idealized ophiolite suite defined by the Penrose conference [5,11]. The Alpine metaophiolites are mostly composed of (now serpentinized) mantle peridotites (mainly harzburgites and minor lherzolite and few dunite) with mafic intrusions and ophicarbonates. A true sheeted dyke complex has never been documented, and metalavas occur in a low percentage. Furthermore, the original thickness of the Jurassic oceanic lithosphere has been strongly modified by the Alpine tectonics. The Alpine metaophiolites are then finally associated with different types of metasediments, only partially comparable with those of less deformed and metamorphosed ophiolites [12]. In the Western Alps, the metaophiolite 
sequences have been distinguished on the basis of their internal structural features, rock association, and metamorphic imprint [12-16]. At a broad scale, metaophiolites are arranged within a relatively simple array: An internal, eclogite facies belt and an external blueschist facies belt [16] (Figure 1B). We focus our study on the eclogite facies belt, and particularly on the metaophiolites exposed in the Aosta Valley and in the Monviso Complex because, due to their weak re-equilibration during the Alpine decompression path, they preserve textural records of the pre-orogenic evolution and of the original geological setting. In this context, we concentrated our investigations on metasediments covering the metaophiolites, with particular attention to their pseudostratigraphic sequence and petrographic features. Since the inception of geological surveys in the Alps in the 19th century, little attention has been generally paid to metasedimentary rocks. Indeed, through selected key sections from different areas of the Western Alps, we demonstrate that distinct occurrences of coupled metaophiolite and metasedimentary sequences are helpful clues for interpreting the evolution of the Jurassic Tethys, their location in the ocean, and involvement in the Alpine orogeny.

Our contribution is aimed at stimulating a discussion on the tectonic settings of the metasedimentary sequences, their relation with the ophiolitic basement, and with the continental slices derived from the palaeo-Europe and palaeo-Adria continental plates involved in the subduction, in order to reconstruct the possible palaeogeographic scenarios.

\section{Geological Setting}

\subsection{The Alps}

The Alps are a mountain belt generated by subduction of the Jurassic Tethys Ocean that occurred in the Cretaceous-Eocene time and subsequent collision between the palaeoAdria and palaeo-European passive continental margins [17-19]. The Tethyan oceanic lithosphere gave rise to the Alpine metaophiolites, while the Adria and Europe domains gave rise to the Austroalpine-Southalpine and Penninic-Helvetic continental systems, respectively $[18,20,21]$. More in detail, the Alpine metaophiolites are the remains of two main branches of the Tethys Ocean, i.e., the Ligurian-Piedmont Ocean and the Valais Ocean, that opened from the Jurassic to the Cretaceous [19,22]. These two branches are commonly referred to as Alpine Tethys [23,24]. The Ligurian-Piedmont Ocean opened between the Briançonnais microcontinent and the Adria palaeo-margin [25]. Its suture gave rise to the Alpine metaophiolites that are mostly exposed in the inner and axial sectors of the Alps. The Valais Ocean opened along the border between the European paleaomargin and the Briançonnais microcontinent [26]. The corresponding Valais units with metaophiolites represent a more external belt that sutured the Briançonnais microcontinent with Europe [22]. The Alpine metaophiolites are frequently imbricated with continentalderived tectonic units, ranging in size from a few kilometers to tens of kilometers (see Figure 1), resulting in the Alpine orogenic wedge [9]. Some of these units exhibit records of the original stratigraphic setting; others are completely dismembered or make tectonic mélanges, such as those occurring in the Central Alps [27].

Subduction processes are attested in the Alps by the occurrence of high-pressure (HP) and ultrahigh-pressure (UHP) mineral assemblages mostly associated with ductile structures particularly concentrated in the Western Alps [16,28-34]. The eclogite facies tectonic units make a more or less continuous belt in the inner (easternmost) parts of the Western Alps, marking the approximate location of the palaeo-subduction zone (Figure 1B). In more external areas of the Western Alps, blueschist facies metamorphic conditions have been documented in the Queyras Schistes Lustrés [16,35,36], while HP greenschists facies metamorphism is recorded in the Briançonnais zone [37] at the front of the belt, attesting to a general increase of the Alpine P-T conditions from the external (westernmost) to the internal (easternmost) sectors of the Western Alps [16,38,39].

The subduction, collision, and exhumation are differently recorded along the entire Alpine belt. As an example, in the Western Alps, subduction was followed by exhumation along a relatively cool path, while in the Central Alps, the decompressional path was ac- 
companied by heating giving rise to a pervasive recrystallisation of rocks under prominent amphibolite facies metamorphic conditions [40,41]. As a result, Alpine rocks variously preserve records of their entire tectono-sedimentary and tectono-metamorphic evolution.

Ages of metamorphism are not homogenous in the Alps. In the northwestern Alps, as in the Aosta Valley for example, the high-pressure metamorphic peaks are comparable among different tectonic units located to the south of the Aosta-Ranzola Line (ARL; Figures 1 and 2), ranging between 49-40 Ma in the Austroalpine klippen and between 45-42 Ma in metaophiolites [42], and around $42 \mathrm{Ma}$ in the Penninic Gran Paradiso units [43]. Comparable ages of the eclogite facies metamorphism are recorded in the Valais units (ca. 42-40 Ma ago) [22]. However, all these ages differ from those revealed by metaophiolites located to the north of the ARL (e.g., $65 \mathrm{Ma}$ in the Valtournenche area) [44] or in the Austroalpine Sesia Lanzo Zone (e.g., 79-65 Ma) [45]. These data clearly suggest that the subducted units in this region of the Western Alps attained their maximum P-T imprint diachronously. Exhumation of the subducted metaophiolites of the Western Alps occurred in a shorter time span, ranging between ca. 42 and $36 \mathrm{Ma}$ [46-49]. The Alpine belt is truncated by the Insubric Line (Figure 1B), a roughly E-W trending fault system, which separates the northern tectonic units, deeply involved in the Alpine orogeny and deformed by N-vergent thrust, from the Southern Alps composed of dominant sedimentary Mesozoic and Tertiary rocks and pre-Alpine metamorphic basement dislocated by S-vergent thrusts [50,51].

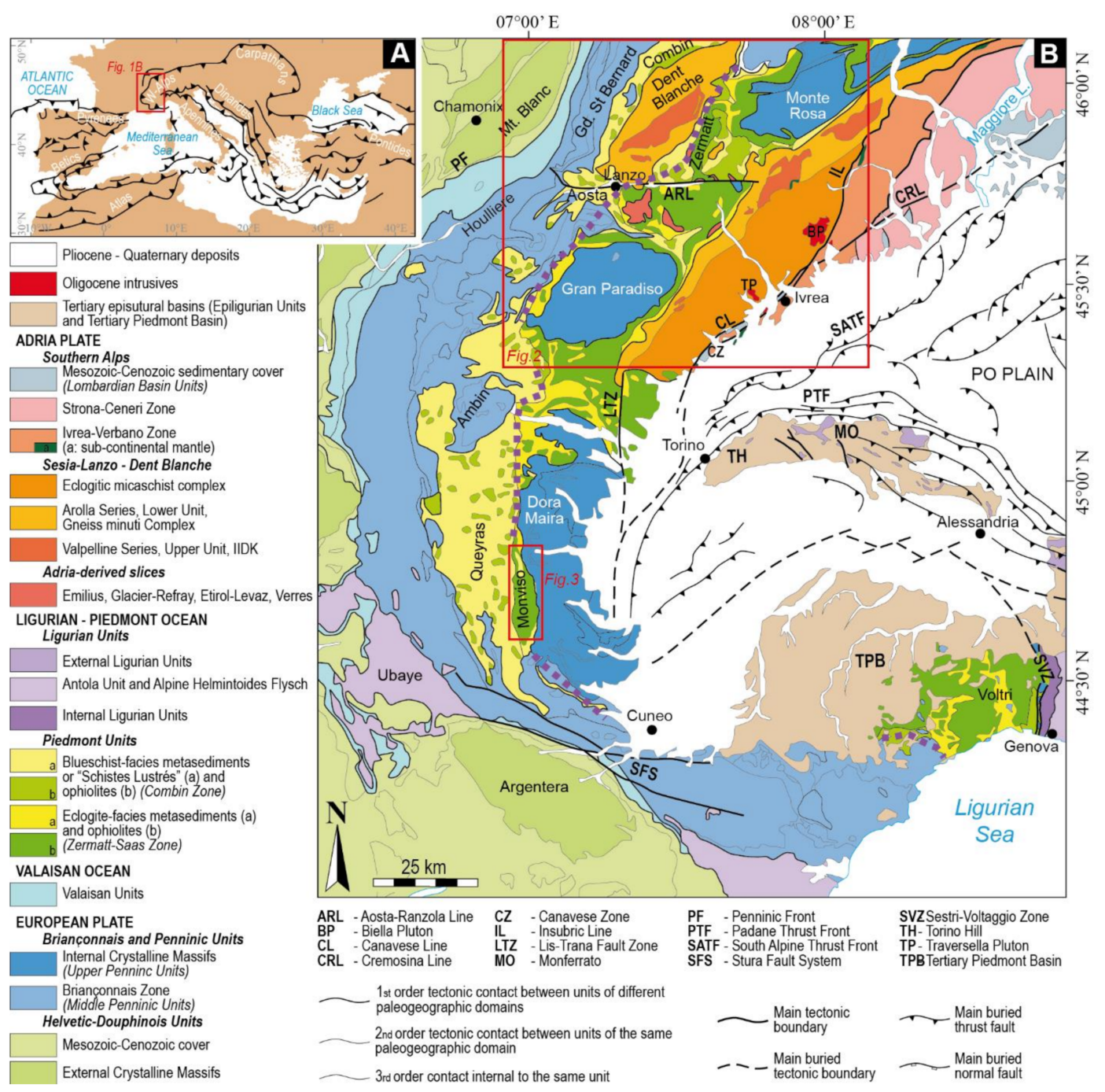

Figure 1. Geographic and geological location of the study areas (modified after Balestro et al. [52] and Festa et al. [53]. (A) Sketch of the Mediterranean area with location of the Western Alps (red rectangle). Main orogenic belts are marked by a black line with 
a triangle on the hanging wall. (B) Tectonic map of the Western Alps showing the distribution of tectonic domains referred to the continental paleo-Adria and paleo-European plates, to the oceanic Ligurian-Piedmont and Valaisan Oceans. The dashed violet line approximately separates the internal eclogite facies belt from the external blueschist and greenschist facies belt of the Western Alps. The main post-collisional fault systems and thrust faults are also reported (see Legend for explanations). Location of Figure 2 (Aosta Valley and Soana valleys) and Figure 3 (Monviso Complex) is reported.

In the Western Alps, where the study areas of the present contribution are located, ophiolites and related sediments derive from the Ligurian-Piedmont Ocean (i.e., the "Piemonte Zone") [54], a composite nappe stack presently sandwiched between the Pennidic and Austroalpine continental domains $[8,9,55,56]$. The Piemonte Zone consists of two main tectonic units: The eclogite facies (HP to UHP) Zermatt-Saas unit and the low-grade (mostly greenschist facies with blueschist facies relics) Combin unit; they were defined in Switzerland [57] and then extended to other sectors of the Western Alps, namely the Aosta Valley region [12-14,58-61]. The Zermatt-Saas metaophiolites extend southwards along the inner arc of the Western Alps (Figure 1), where they constitute other eclogite facies metaophiolites such as the Monviso Complex [12,62,63], the Rocciavrè metaophiolite [64], and the Voltri Group [65]. The Combin unit extends to the south in the Queyras area (Figure 1) [66,67] constituting the external blueschist facies belt of the Western Alps (Figure 1B). Finally, the eclogite facies metaophiolites of the Valaisan Ocean are exposed in the outermost sectors of the Western Alps (Figure 1B).

\subsection{The Aosta Valley}

Located in the northwestern part of the Alpine belt (Figure 2), the Aosta Valley represents a natural geotraverse through the Alpine orogenic wedge, from the innermost continental units of the Sesia-Lanzo Zone to the oceanic units of the Piemonte Zone until the continental Penninic and Helvetic units.

In the southern Aosta Valley, to the south of the ARL where some of our study areas are located (Figure 2), the metaophiolites are dominated by mantle-derived (now serpentinized) peridotites intruded by gabbro and rodingitized gabbro dykes, and minor mafic rocks, metatrondhjemite, and metasediments comprising quartzite (probably from radiolarite), marble, and calc schists [68-73]. These metaophiolites are mostly comparable to the Zermatt-Saas unit, showing a dominant early Alpine subduction-related metamorphic imprint under eclogite facies conditions, variously retrogressed under greenschists facies conditions [42,69,74-78]. More recently, the metaophiolites exposed in the southern Aosta Valley have been subdivided into several tectonic units, according to their rock assemblage and dominant metamorphic imprint related to the Alpine orogenesis [79]: Among these, there are the Zermatt-Saas and Grivola-Urtier units, that were metamorphosed under eclogite facies conditions; the Combin and Aouilletta units, characterized by calc schists and minor amounts of ophiolites showing prevalent greenschist facies mineral assemblages; and the Cogne units, interpreted as continental cover sequences but included in the Piemonte Zone. The metaophiolites of the southern Aosta Valley are thrust over the northern end of the Pennidic Gran Paradiso massif and in turn overthrust by slices (or klippen) of Austroalpine continental crust (i.e., the Mount Emilius, Glacier-Rafray, Tour Ponton, and Acque Rosse tectonic units [42,80,81] (Figure 2), that show a comparable Alpine metamorphic evolution. 


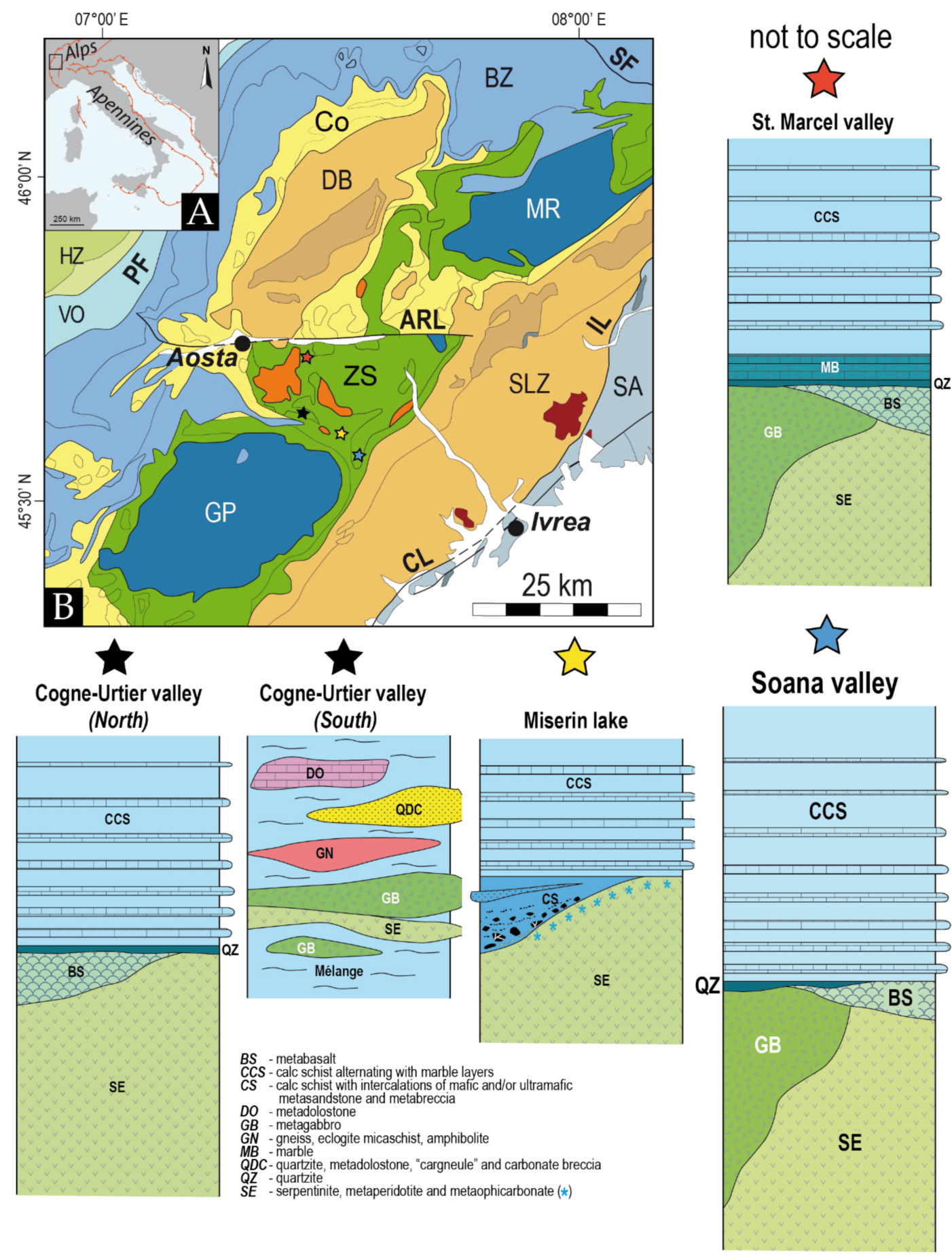

Figure 2. Geographic location and geological context of the study areas in the Aosta Valley region and Soana valley. (A) Geographic location of the study area in the NW-Alps (Italy). (B) Tectonic map of the NW Alps, modified after Balestro et al. [52], with location of the St. Marcel valley (red star), Cogne-Urtier valley area (black star), Miserin lake area (yellow star), and Soana valley (blue star). Simplified lithostratigraphic columnar sections of the St. Marcel valley, Cogne-Urtier valley (North and South), Miserin lake, Soana valley are reported. Palaeo-European domain: Briançonnais Zone (BZ); Gran Paradiso Penninic nappe (GP); Monte Rosa Penninic nappe (MR); Helvetic Zone (HZ); Ligurian-Piedmont Ocean: Combin Zone (Co); Zermatt-Saas Zone (ZS); Valaisan Ocean (VO); palaeo-Adria domain: Dent Blanche nappe (DB); Sesia-Lanzo Zone (SLZ); Southern Alps (SA); eclogitic Lower Austroalpine outliers (orange area). Main fault systems: CL: Canavese Line; ARL: Aosta-Ranzola Line; IL: Insubric Line; PF: Penninic Front; SF: Simplon Fault. 


\subsection{The Metaophiolite Monviso Complex}

Located in the southwestern part of the Alpine belt (Figure 1B), the Monviso corresponds to an area wherein one of the major and better investigated eclogitized remnants of the Ligurian-Piedmont oceanic lithosphere in the Western Alps (i.e., the metaophiolite Monviso Complex) is exposed. The Monviso Complex is tectonically interposed between the continental Dora Maira crystalline Massif and the Queyras Schistes Lustrés Complex, to the East and West, respectively [61,62]. The Dora Maira Massif represents a slab of the paleo-European margin, which consists of various tectonic units, differing from each other for their lithostratigraphic features, Alpine metamorphic P-T peaks (from blueschistto eclogite-coesite facies), and structural position [82-87]. The Queyras Schistes Lustrés Complex, which is separated from the Monviso Complex along a major ductile fault [88,89], represents the external part of the Alpine accretionary wedge [90] (Figure 1B). It consists of carbonate-rich metasedimentary succession with metaophiolite bodies [67,91], which were metamorphosed under blueschist facies conditions during the late Cretaceous-early Eocene subduction of the Ligurian-Piedmont Ocean $[92,93]$ and pervasively deformed during Alpine tectonics [36].

The structure of the Monviso Complex, which consists of several tectonically juxtaposed units $[62,63,94-96]$, resulted from three main tectonic stages developed during (i) the Late Cretaceous to Middle Eocene subduction, (ii) the Late Eocene-Early Oligocene collision and W-verging accretion, and (iii) the Late Oligocene to Neogene westward tilting, which was driven by crust and mantle indentation and doming of the Dora Maira Massif $[97,98]$. The partially preserved subduction-related mineral assemblages constrain the P-T peak metamorphic conditions roughly at $2.5 \mathrm{GPa}-550{ }^{\circ} \mathrm{C}[96,99,100]$.

The metaophiolite sequence of the Monviso Complex consists of serpentinite, metagabbro, metabasalt, and metasedimentary rocks [62]. The original upper mantle peridotite was intruded during Late Jurassic by gabbro (163 $\pm 2 \mathrm{Ma}$ in age) [101] and quartz-diorite $(152 \pm 2 \mathrm{Ma})$ [102]. An association of talc-chlorite and serpentine schists with blocks of metagabbro occurs throughout the Monviso Complex, and it has been interpreted as a remnant of intra-oceanic detachment faulting (i.e., the "Baracun Shear Zone" of Festa et al. [103]) (Figure 3). The Baracun Shear Zone separates serpentinite and metagabbros in its footwall from metabasalt and metasediments in its hanging wall. The metabasalt includes pillow metalavas and volcanic metabreccia. The metasediments derive from two different successions, which have been referred to as a Late Jurassic syn-extensional succession and a Cretaceous post-extensional one [52]; extension is related to the Late Jurassic spreading resulting in the formation of the Ligurian-Piedmont oceanic basin (see below). 


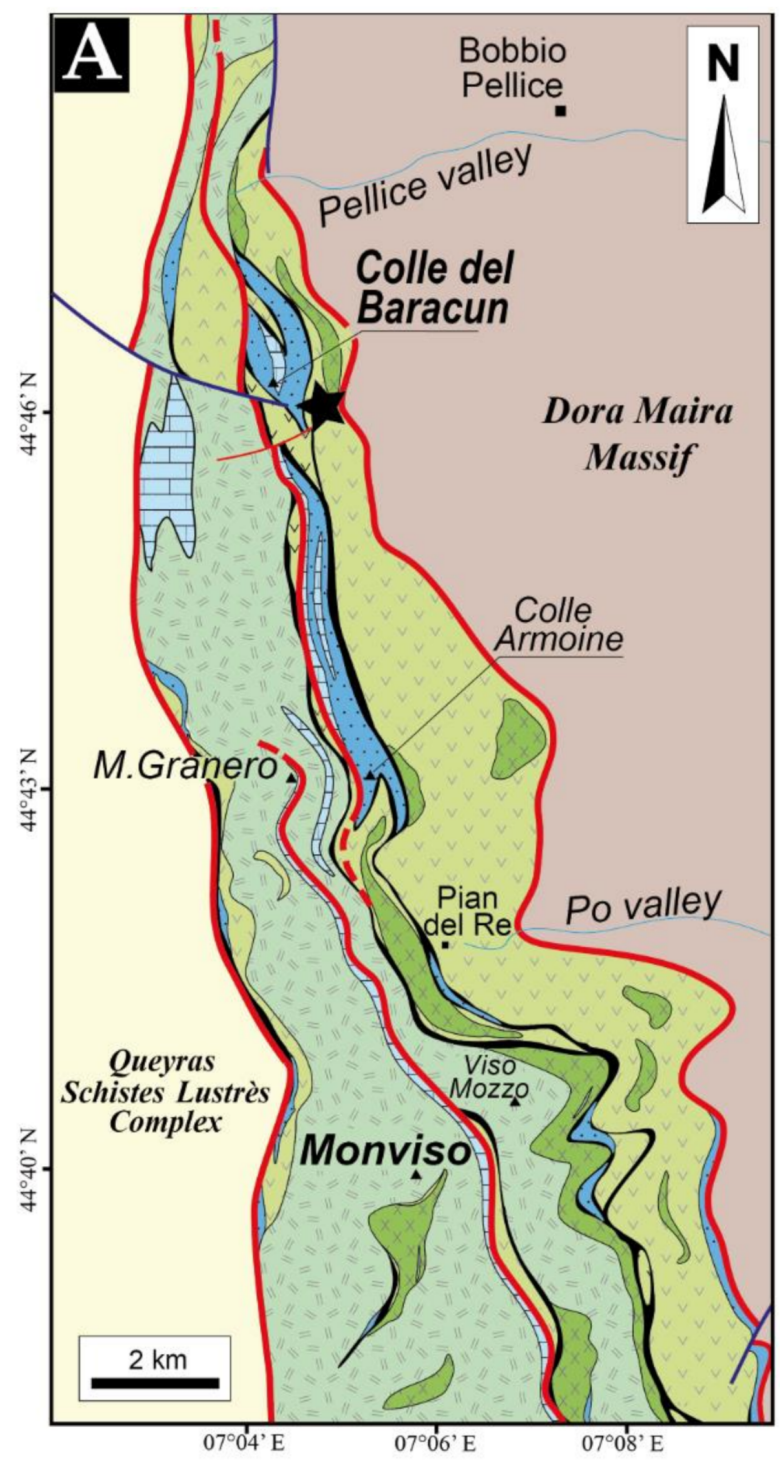

Undifferentiated Queyras Schistes Lustrès Complex

Undifferentiated Dora Maira Massif

\section{Monviso metaophiolite Complex}

Post-extensional succession (Early Cretaceous)

Metachert, withish marble and calc schist alternating with layers of marble and quartz-rich schist

Syn-extensional succession (Late Jurassic)

Metabasalt with relics of pillow and breccia textures

Calc schist with intercalations of mafic metabreccia and metasandstone

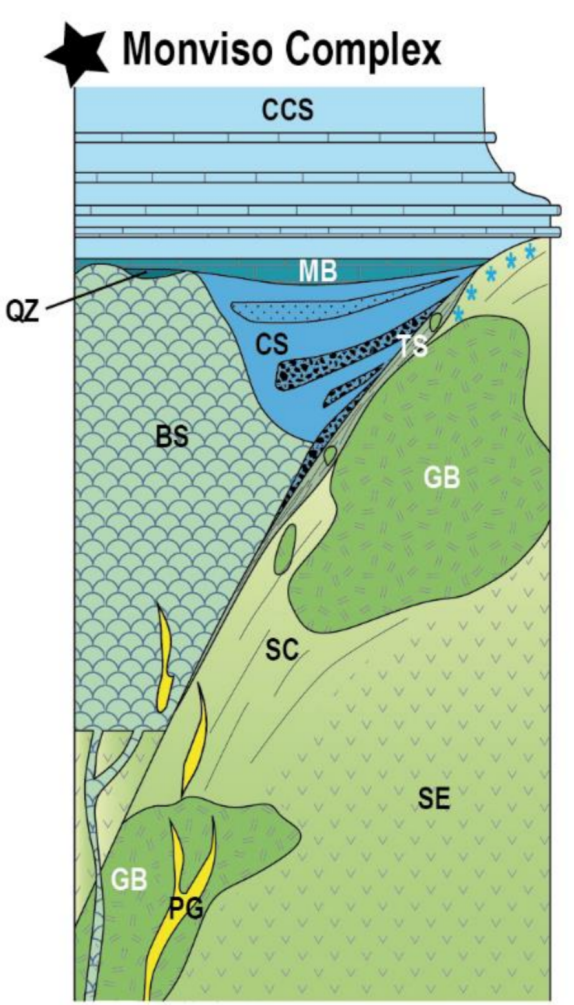

BS - metabasalt

CCS - calc schist alternating with marble layers

CS - calc schist with intercalations of mafic and/or ultramafic metabreccia and metasandstone

GB - metagabbro

$M B$ - marble

$P G$ - plagiogranite

$Q Z$ - quartzite

SC - serpentine schist

$S E$ - serpentinite, metaperidotite and metaophicarbonate (*)

TS - talc-chlorite schist and serpentine schist
Baracun Shear Zone (Late Jurassic)

Talc-chlorite schist and serpentine schist with blocks of metagabbro

Mantle rocks (Middle-Late Jurassic)

Mg-Al metagabbro and Fe-Ti metagabbro

Serpentinized metaperidotite

with horizons of metaophicarbonate

Lithological contact

- Syn-metamorphic tectonic contact

Post-metamorphic fault

Figure 3. (A) Geological map of the metaophiolite Monviso Complex; modified from Balestro et al. [61]. (B) Simplified stratigraphic columnar section of the Monviso metaophiolite is also reported. 


\section{Methods}

The most significant results from selected metaophiolite and metasedimentary successions of the Western Alps are reviewed. These data are implemented with new original data obtained on metasedimentary successions by field mapping at various scales (from 1:10,000 to 1:500). Tens of thin sections were then selected for petrographic descriptions under optical microscope (Zeiss Axioscope polarizing transmitted light; Zeiss, Jena, Germany) for documenting the main HP mineral assemblages. The aim is to synthesize the most representative examples of metasedimentary successions associated to metaophiolites, and to reconstruct their pseudostratigraphic features for inferring possible scenarios of the original geological setting.

\section{Metasedimentary Tectono-Stratigraphic Successions}

\subsection{Ophiolitic Metasediments across the Southern Aosta Valley Region}

Our study areas are located in the southern sector of the Aosta Valley region (see Figure 2). The metaophiolite structural position is between the underlying Upper Penninic Gran Paradiso nappe and the overlying Austroalpine klippen. We focus our investigation on the metasedimentary tectono-stratigraphic successions covering the metaophiolites of the St. Marcel valley and the Cogne-Urtier valley-Champorcher area (see Figure 2). Two main types of those successions are recognizable. The first type comprises quartzite (probably from radiolarite), marble, and calc schists $[68,69,104,105]$. These metasediments directly cover the ophiolitic metabasalts or metagabbro, often associated with manganeseor sulphide-ore deposits. The second succession type consists of ophicarbonate breccias or mixed mafic-ultramafic breccias, which directly lie upon serpentinized mantle peridotites, followed by calc schists with (scarce) ophiolitic interbeds [106,107]. A few case studies were selected as being the most significant and representative of distinct metaophiolite suites with associated metasediments, as described below.

\subsubsection{The St. Marcel Valley Section}

The St. Marcel valley is a right tributary of the Aosta valley, it is north-south oriented, and extends for about $8 \mathrm{~km}$ in length (see Figure 2). In the St. Marcel valley, the metaophiolite basement is almost unique, being composed of crustal lithologies of the oceanic lithosphere, and not of mantle serpentinites as in most sectors of the Aosta valley. Metaophiolites consist of eclogite facies Fe-Ti- and Mg-metagabbros, metabasalts represented by glaucophanites with garnet and lawsonite (now pseudomorphed) and enclosing eclogite boudins, garnet-chloritoid-glaucophane-chlorite-bearing schists, and minor talc schists $[69,104,105,108]$. These rocks include a well-known $\mathrm{Cu}-\mathrm{Fe}$ sulfide mining district and a Mn-rich deposit interpreted as palaeo-hyrothermal fields referable to the Jurassic oceanic environment [108-110].

Metasediments occur on both sides of the St. Marcel valley; their thickness, although falsified by multiple folding, ranges from a few meters up to $800 \mathrm{~m}$ going from the north to the south along the valley. The metasediments are always floored by metabasalt or metagabbro, partially retrogressed under greenschist facies conditions and often enclosing eclogite boudins, whilst a stratigraphic contact with serpentinite has never been observed. The contact between metaophiolite and metasediments is commonly sharp and marked by actinolite schists, with scarce repetition of metaophiolite layers within metasediments.

The metasedimentary sequence starts with quartzites followed by fine-grained, impure marbles (Figure 4A-D). Several types of quartzites were recognized (Figure 5A-D): Garnetbearing micaceous quartzites with epidote, clinopyroxene, blue-amphibole, and relict cummingtonite included in garnet; manganiferous quartzites (probably deriving from radiolarite); micaceous quartzites; amphibole-chlorite-rich quartzites; carbonate-rich and garnet-bearing micaceous quartzites; quartz-chloritoid-rich mica schists. In the northern St. Marcel valley, metabasalts and quartzites are associated with sulfide- and Mn-rich ore deposits [110]. Marbles consist of impure, fine-grained pale-grey marbles and micaceous marbles (Figure 5E,F). The sequence ends with calc schists consisting of siliceous marly 
limestone (marble) alternating with shaly beds (Figures 4E,F and 5G,H), including minor quartz-carbonate-rich micaschists. The contact between quartzites or micaschists and the calc schists is often marked by quartz-rich calc schists or by graphitic calc schists.
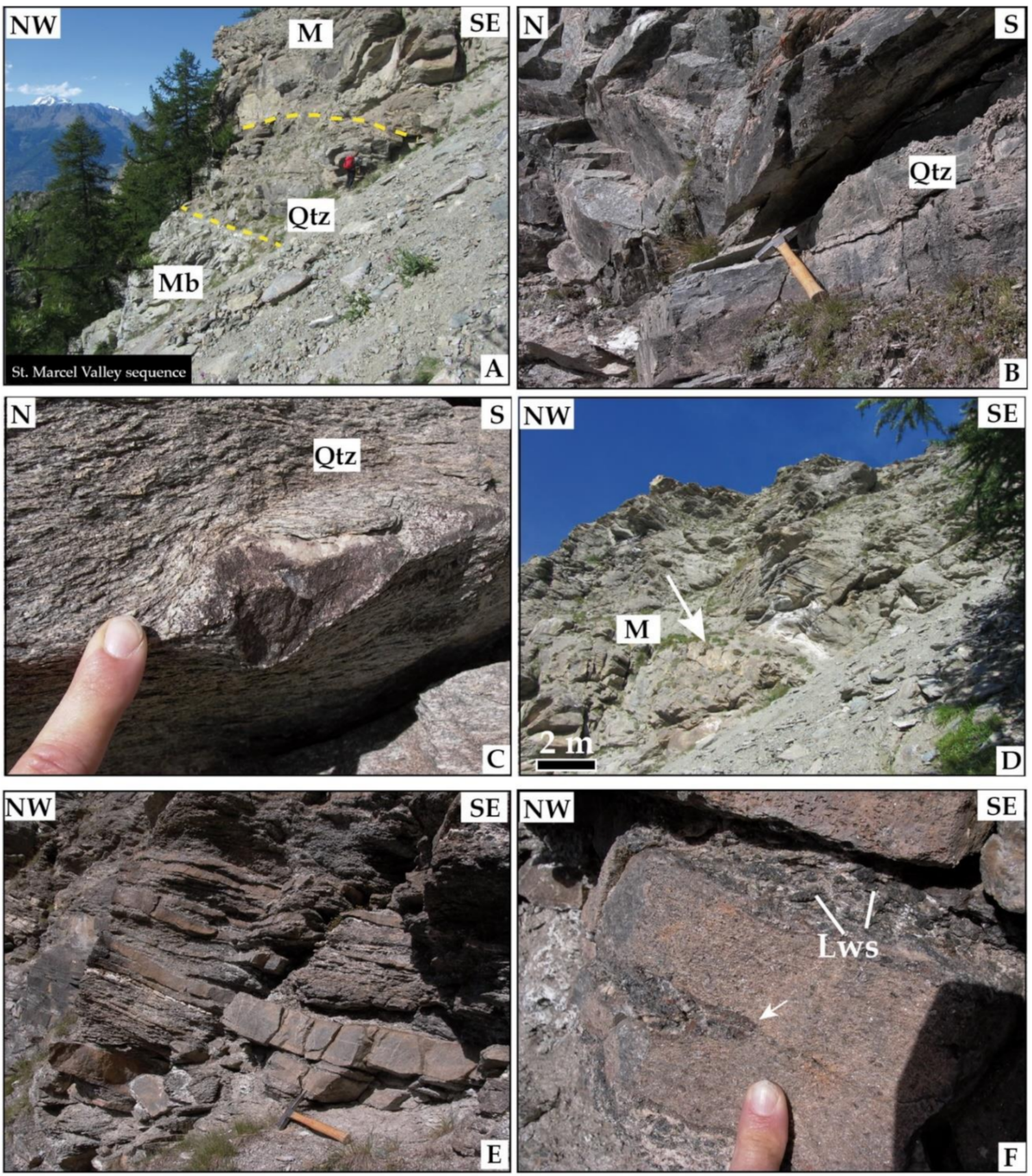

Figure 4. General view of the St. Marcel valley metasedimentary successions covering the metaophiolites. (A) Quartzites (Qtz) and fine-grained marbles (M) on top of metaophiolites represented by mafic rocks and actinolite schist (Mb). (B) Closeup view of quartzite. (C) Micaceous quartzite with quartz porphyroclast covered by a thin film of Mn-rich oxide. (D) Grey to yellow marble covering the quartzite. (E) Calc schist consisting of siliceous marly limestone alternating with shaly beds. (F) Close-up view of calc schist: Marble layer including a folded micaceous layer (arrow). Lws: millimeter-scale pseudomorphs on lawsonite now composed of mica-epidote-albite aggregate. 
Metaophiolites and metasediments are characterized by a common structural evolution that produced a regional-scale subduction-related foliation extended at the scale of the entire valley and marked, in the metaophiolites by glaucophane, garnet, and omphacite, and in the metasediments by garnet, chloritoid, and pseudomorphed lawsonite. Mineral retrogression acquired during exhumation under greenschists facies conditions is poorly recorded. Estimation of the peak P-T conditions for the St. Marcel valley eclogites provides $\mathrm{T}=550 \pm 60^{\circ} \mathrm{C}$ and $\mathrm{P}=2.1 \pm 0.3 \mathrm{GPa}$ [108]. These $\mathrm{P}-\mathrm{T}$ values are higher than those previously obtained in the same area $\left(\operatorname{Tmax}=550 \pm 20^{\circ} \mathrm{C}\right.$; Pmax $=1.2 \pm 0.1 \mathrm{GPa}$ performed by Martin and Tartarotti [69] on eclogite boudins; $\operatorname{Tmax}=500^{\circ} \mathrm{C} ; \mathrm{Pmax}=1.4 \mathrm{GPa}$ obtained on eclogite Mn-assemblages by Brown et al. [111], Mottana [112], and Martin and Kienast [76]. The eclogitic imprint is of Eocene age (45-42 Ma) like in the overlying Austroalpine tectonic units (i.e., the Mount Emilius klippe: 49-40 Ma) [42].

\subsubsection{The Cogne-Urtier Valley Sections}

The Cogne valley is right tributary of the Aosta valley and extends for about $32 \mathrm{~km}$ in length. It is southeast-northwest oriented in its upper segment (named Urtier valley) and mid segment (named Grand'Eyvia valley), becoming north-south oriented in the lower segment, towards the confluence with the main stream of the Aosta valley, i.e., the Dora Baltea river (see Figure 2).

The tectono-metamorphic setting of the Cogne area is complicated by the presence of different tectonic units of both continental and oceanic origin, locally intensely deformed and transposed together. They include the Middle and Upper Penninic continental basement units (i.e., the San Bernardo and Gran Paradiso Nappes, respectively; Figure 2) with their own metasedimentary covers, closely set one upon the other, and the oceanic metaophiolites of the Piemonte Zone. The metaophiolites are exposed all along the northern border of the Gran Paradiso massif and extend to the North (i.e., towards the St. Marcel valley) and to the East, along the Urtier valley. They are tectonically overthrust upon all the Penninic basement and cover units and are in turn covered by hectometer- to kilometer-scale Austroalpine tectonic slices, such as the Mount Emilius and Tour Ponton units presently occurring as klippen because of the erosion of the uppermost metaophiolites. Other minor Austroalpine slices are pinched within the metaophiolites in the highest Urtier valley, near the border with the Champorcher valley [81,113].

For their rock assemblages and metamorphic imprint, the Cogne-Urtier valley metaophiolites have been compared to the Zermatt Saas Zone, although some authors have attributed these metaophiolites to differents units (or sub-units), on the basis of their rock assemblages and metamorphic imprint [79,114-117]. For simplicity, the Cogne-Urtier metaophiolites are here referred to "Zermatt Saas metaophiolites". They consist of antigorite- Ti-clinohumite serpentinites, Fe-Ti- metabasalts transformed into glaucophanites with garnet and lawsonite (now pseudomorphed) enclosing eclogite boudins, Mg- and Fe-Ti metagabbros, and serpentinites $[54,75,79,115-119]$. Similar to the metaophiolites described in the St. Marcel valley, the Cogne-Urtier metaophiolites are mostly characterized by high-pressure metamorphism variously retrogressed under greenschists facies conditions. Estimation of the peak $\mathrm{P}$ - T conditions for the Urtier valley eclogites provides $\mathrm{T}=500 \pm 50^{\circ} \mathrm{C}$ and $\mathrm{P}=1.2 \mathrm{GPa}$ [77], comparable to those of the St. Marcel valley $\left(\mathrm{T}=550 \pm 60^{\circ} \mathrm{C}\right.$ and $\left.\mathrm{P}=2.1 \pm 0.3 \mathrm{GPa}\right)$ [108] although showing lower pressure conditions. These P-T values are also comparable with those obtained in the Gran Paradiso $\left(\mathrm{T}=500-520^{\circ} \mathrm{C}\right.$ and $\mathrm{P}=1.8-2.0 \mathrm{GPa}$ of Eocene age at $42 \mathrm{Ma}$ ) [43] and in the overlying Austroalpine tectonic units where the eclogitic imprint has been estimated of $\mathrm{T}=440-550^{\circ} \mathrm{C}$ and $\mathrm{P}=1.2-1.5 \mathrm{GPa}$, still of Eocene age (i.e., the Mount Emilius klippe: 49-40 Ma) [42]. The ages of the eclogitic peaks differ from those revealed by metaophiolites from the northern Aosta Valley (e.g., $65 \mathrm{Ma}$ in the Valtournenche area) [44] or in the Sesia Lanzo Zone (e.g., 79-65 Ma) [45], suggesting that the subducted tectonic units in this region of the Western Alps attained their maximum P-T imprint diachronously. Exhumation of the subducted metaophiolites of the Western Alps occurred in a time span ranging between ca. 42 and $36 \mathrm{Ma}$ [46-49]. 
Metaophiolites and related metasedimentary rocks of the Cogne-Urtier valley area show different features in the northern and southern sectors.

In the northern sector, near the Corona lakes and towards the orogenic divide with the St. Marcel valley, metaophiolites are mostly represented by mafic rocks associated to quartzites and calc schists (see also Figure 2, Cogne-Urtier valley North section). These latter are made of marble layers regularly alternating with micaceous layers; centimetersized lawsonite porphyroblasts now pseudomorphed by white mica + clinozoisite typically characterize these rocks (Figure 6A) together with chloritoid (Figure 7A). North of the Cogne village, metaophiolites include a kilometer-sized slice of serpentinite hosting the well-known Cogne magnetite mineralization, the biggest of the Alps [120-124] and some small-sized Cu-Fe sulphide stockworks. Recent works by Toffolo et al. [124] have shown the hydrothermal origin of this magnetite mineralization and the primary magmatic nature (troctolite composition) of the hosting serpentinite. U-Th- $\mathrm{Pb}$ dating of magnetite-associated uraninite constrains the formation of the deposit to Late Jurassic (ca. $150 \mathrm{Ma}$ ), during an advanced stage of the opening of the Tethys supporting a genetic affinity of this serpentinite with the Zermatt Saas metaophiolites hosting the $\mathrm{Cu}-\mathrm{Fe}$ hydrothermal mineralizations of the St. Marcel valley.

The right side of the Urtier valley (see also Figure 2, Cogne-Urtier valley South section) is characterized by the occurrence of metadolostones, marble, metaconglomerates, and metasandstones (i.e., the "Faisceau de Cogne" unit, or "FDC") [125], easily recognizable in the field for their white-yellowish color (Figure 6B-D). These metasedimentary rocks often show an evident compositional layering marked by carbonate-rich layers alternating with quartzite layers or calc-mica schists with quartz porphyroclasts (Figure 7B). This layering can be attributed to the effect of pervasive isoclinal folding of $D_{1}-D_{2}$ Alpine phases (Figure 6C) and shearing, likely occurred under high-pressure metamorphic conditions, as suggested by petrographic features of carbonate-rich rocks (Figure 7C,D). These metasedimentary carbonatic rocks are strongly sheared and tectonized, and mechanically mixed with serpentinites to form an assembly of tectonic slices about 300-500 m thick. This mixing can be recognized also at the micro-scale (Figure S1). The FDC unit likely derives from sedimentary cover sequences of the Penninic domain. Moreover, not far away from the Urtier valley, in the Grand'Eyvia valley (lower part of the Cogne valley), similar carbonate-rich metasediments of Carboniferous to Liassic age are in stratigraphic contact with the Gran San Bernardo basement, and thus interpreted as the Gran San Bernardo original sedimentary cover (i.e., the so called "Ensemble A" of Elter [54]). Similarly, in the Valnontey and Valsavaranche valleys, the metasedimentary cover of Gran Paradiso is well recognizable, even if transposed with metagranites [126,127].

In the lower right side of the Urtier valley, a series of garnet-bearing calc schists and micaschists rich in quartz porphyroclasts or $\mathrm{mm}$-cm thick layers (Figure 6E) are in tectonic contact with the serpentinite slices and the underlying FDC unit and attributed to the Zermatt-Saas metaophiolite [79]. 

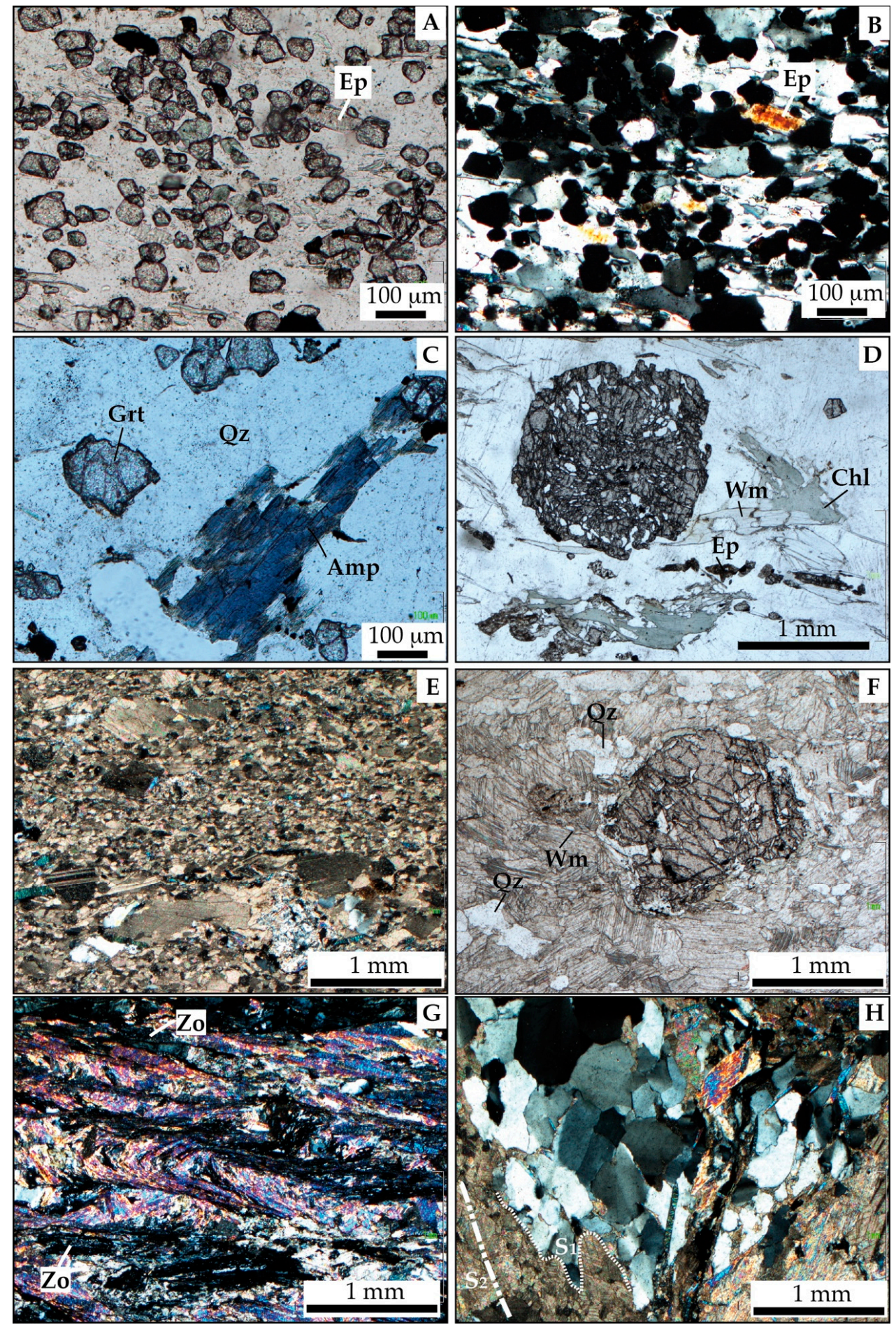

Figure 5. Photomicrographs of the St. Marcel valley metasediments. (A) Garnet-bearing micaceous quartzites with epidote (Ep); plane polarized light (sample EM286). (B) Same view as (A) under crossed nicols. (C) Garnet (Grt)-bearing quartzite (Qz) with blue-amphibole (Amp); plane polarized light. (D) Greenish micaceous quartzite with garnet poikiloblast, chlorite (Chl), epidote, white mica (Wm); plane polarized light (sample EM296). (E) Fine-grained marble (with yellow coating); crossed nicols (sample EM295). (F) Quartz-rich micaceous marble; plane polarized light (sample EM272). (G) Micaceous layer from calc schist; graphite levels and zoisite (Zo); crossed nicols (sample EM283). (H) Quartz-bearing marble from calc schist; a thin layer of quartz is folded by $D_{2}$ isoclinal fold showing relict $S_{1}$ foliation near the $\mathrm{F} 2$ fold hinge; crossed nicols (sample EM292). Mineral abbreviations on pictures according to Whitney and Evans [128] except for white mica (Wm). 

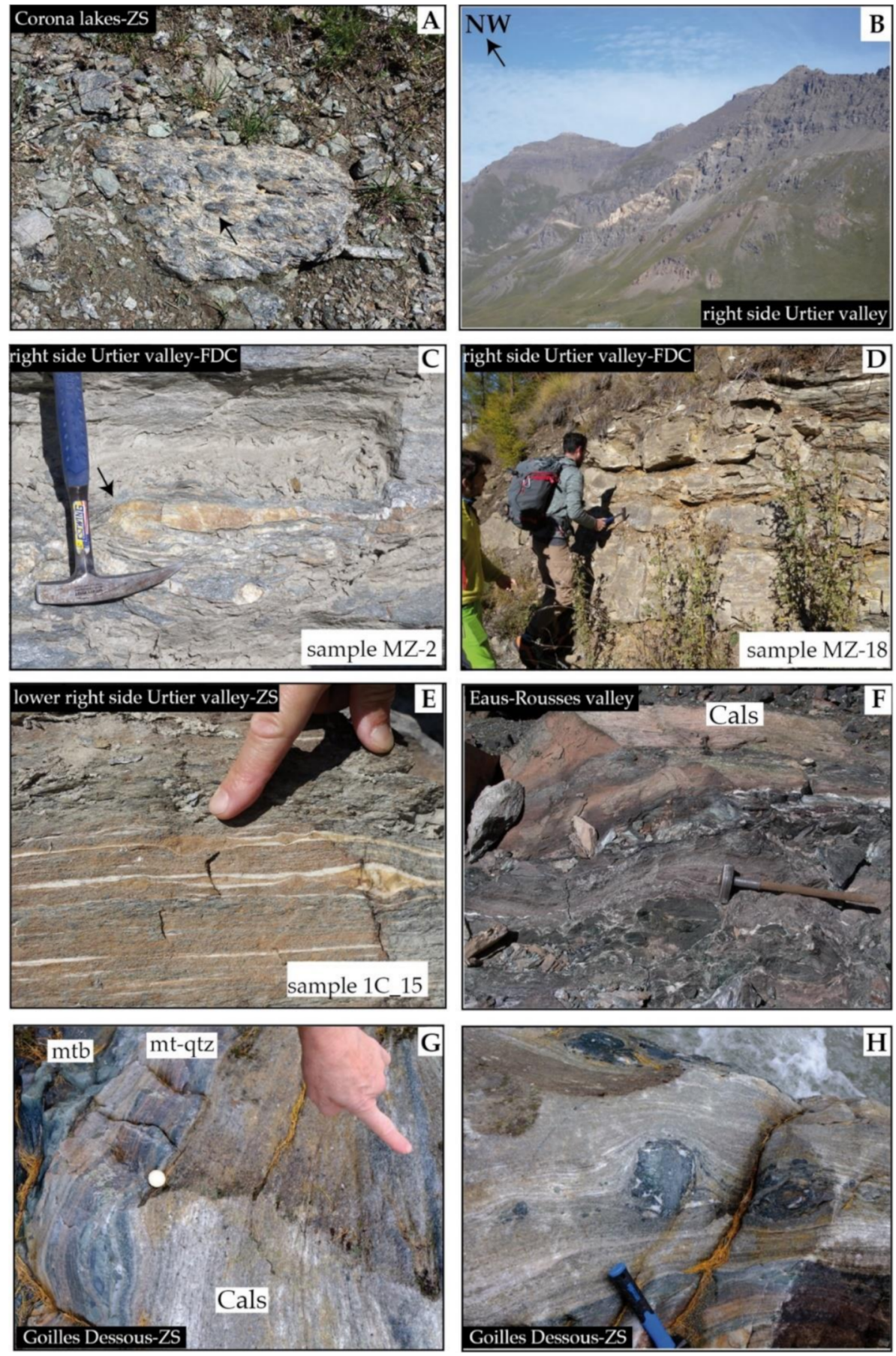

Figure 6. General view of the Cogne-Urtier valley metasedimentary successions. (A) Calc schist of the Corona lakes area (north of the Cogne village) with centimeter-sized pseudomorphs of white mica + clinozoisite replacing lawsonite. (B) Panorama of the dextral side of the Urtier valley showing metadolostone and marble (white rocks) of the Faisceau de Cogne (FDC) unit interbedded within calc schists and metaophiolites of the Zermatt-Saas unit. (C) Example of the FDC lithologies: Quartz-rich layers and porphyroclasts interbedded with marble by isoclinal folding. (D) FDC: Greyyellow marble (thicker layers; see also Figure 7C) alternating with white mica-chlorite-albite-schists (partly dissolved by weathering). (E) Zermatt-Saas metaophiolite of the Urtier valley (lower right side): calc schists rich in quartz-layers deformed by destral (top to East) shearing (see also Figure 7E,F). (F) Southern side of the Urtier valley: Serpentinite metabreccia with a carbonate-rich matrix interbedded with calc schist (Cals) in the Eaus-Rousses valley. (G) Southern side of the Urtier valley: Mn-garnet-quartzite (mt-qtz) in contact with metabasite ( $\mathrm{mtb}$ ) grading to micaschist and calc schist (near Goilles Dessous bridge). (H) Details of metabasite clast included in the calc schist shown in Figure 6G. 

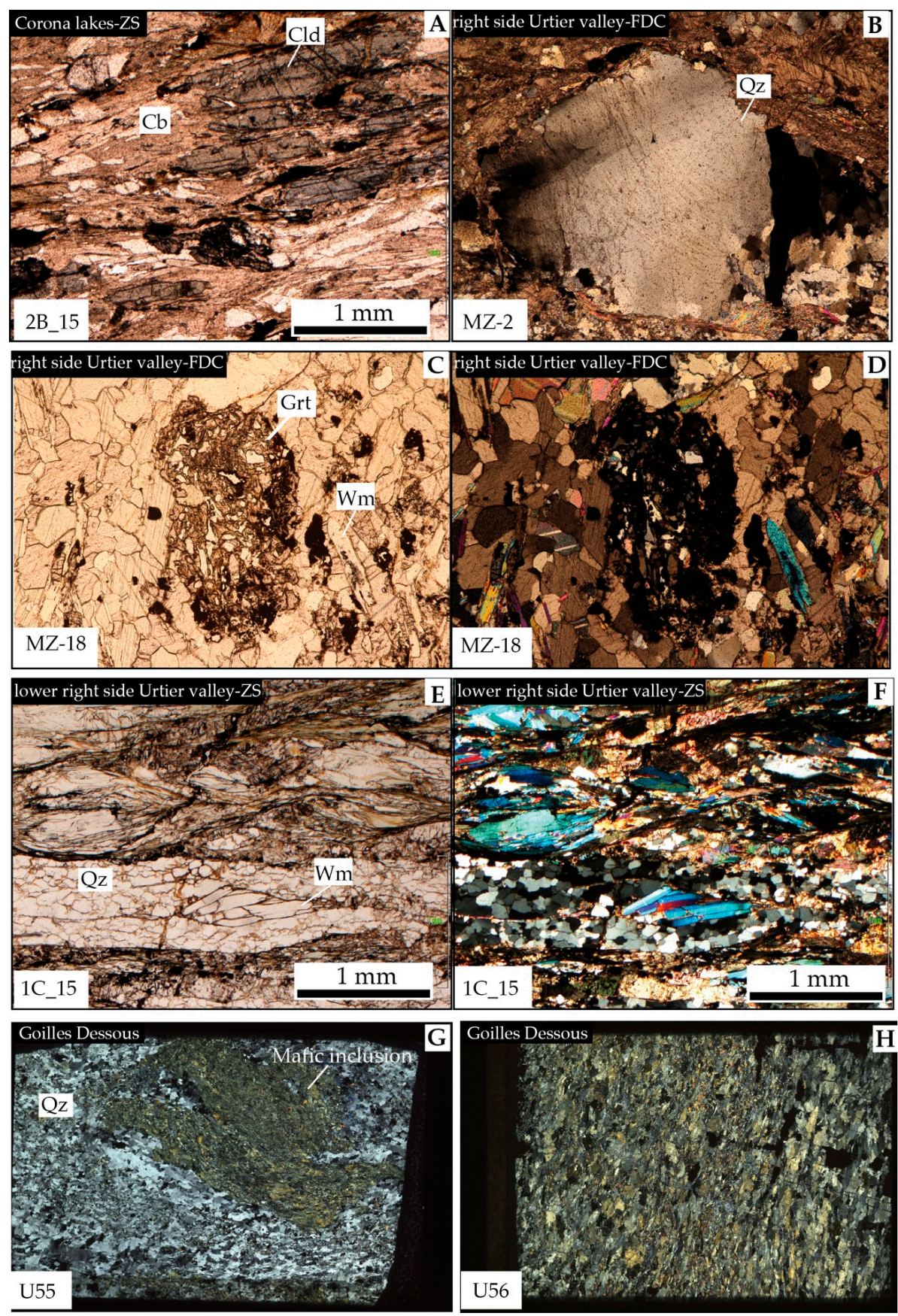

Figure 7. Photomicrographs of the Cogne-Urtier sequences. (A) Zermatt-Saas metaophiolite north of Cogne: Calc schist with chloritoid (Cld) and carbonate (Cb); near the Corona lakes; plane polarized light (sample 2B_15). (B) FDC (right side of the Urtier valley): recrystallized quartz porphyroclast in quartz-rich marble (right side of the Urtier valley); crossed nicols (sample MZ-2; magnification: 10×). (C) FDC (right side of the Urtier valley): Garnet-bearing marble (see Figure 6D for the field view); plane polarized light (sample MZ-18). (D) Same picture of Figure 7C; crossed nicols. (E) Zermatt-Saas metaophiolite, lower right side of the Urtier valley: Calc schists with quartz-white mica layers defining a compositional layering. The rock is deformed by dextral (top to the East) shear developing C-type shear bands and white mica fishes. Lower half: A white mica "fish" (inside quartz layer) with (001) parallel to the shortest side of the fish. Synthetic slip on (001) is inferred; plane polarized light (sample 1C_15). (F) Same of Figure 7E, crossed nicols. (G) Southern side of the Urtier valley, near the Goilles Dessous bridge (see Figure 6G,H for field view): Quartzite including a clast of foliated mafic rock consisting of clinopyroxene; crossed nicols (sample U55; field of view: $3 \times 2 \mathrm{~cm}^{2}$ ). (H) Close-up view of the mafic rock; crossed nicols (sample U56; field of view: $3 \times 2 \mathrm{~cm}^{2}$ ). Mineral abbreviations according to Whitney and Evans [128] except for white mica $(\mathrm{Wm})$. 
The Zermatt-Saas metaophiolites extensively crop out along the axial Urtier valley and within the sinistral tributary valleys (Valnontey, Valleille, Bardoney, and Vallon des Eaux Rousses valleys), up to the orogenic divide with the Champorcher valley, to the east. They constitute the so-called Grivola-Urtier unit [79,117] or the Lower Ophiolitic Unit [114], which overlays the Upper Penninic Gran Paradiso Nappe. Similarly to the northern side of the Urtier valley, the Zermatt-Saas metaophiolites exposed in the southern side (Valnontey valley) are interlayered with carbonatic rocks of the Penninic covers. Here, metaophiolites were in fact transposed under high-pressure conditions with dolostones and limestones of the Penninic covers, as suggested by the occurrence of lawsonite pseudomorph in calc schists (for example, at the Loie lake, P. ta Fenilia, Loson Pass, "the Tuf "peak, Trajo Pass) [118]. However, along the southern side of the Urtier valley and its lateral valleys, the metaophiolites mostly exhibit a tectonic setting, which differ from that recognized in the opposite side and in the St. Marcel valley, for showing a chaotic arrangement with blocks and/or slices of various size and composition, similar to a mélange. The largest ophiolitic slices, up to hundreds of meters wide, consist of serpentinite including chlorite-schist layers (probably representing original dykes) which envelop huge (hectometer scale) gabbro intrusions or mega-boudins (e.g., the Pointe Noire Fe-Ti metagabbro). More fine-grained material is represented by $\mathrm{dm}$ - to $\mathrm{cm}$-sized mafic or ultramafic blocks and clasts embedded in a carbonate matrix [116,117]. These metabreccias may be tectonically transposed with calc schists (e.g., Eaus-Rousses valley; Figure 6F), serpentinite (e.g., Loie lake), or metagabbro (e.g., near Champlong). A direct and sharp contact between the ophiolitic basement and its metasedimentary cover is only locally well preserved in this sector of the Cogne area [116], such as near the Broillot alm or at Mt. Poucet, where some huge (hundreds of meters thick) eclogitic metabasalts or partly retrogressed metabasites are in contact with thick micaceous calschists. Near the Goilles Dessous bridge, Mn-garnet-quartzite grading to micaschists and calc schists are in direct contact with metabasite (Figures 6G,H and 7G,H); however, also in this latter case, quartzites in contact with metabasite include $\mathrm{cm}$-thick layers or clasts of clinopyroxene-rich mafic rock (see Figure $6 \mathrm{G}, \mathrm{H}$ ).

This mélange-like rock assemblage exposed along the southern side of the Urtier valley suffered a tectonic evolution common with that of the underlying Gran Paradiso Nappe dominated by a regional-scale high-pressure foliation marked, in the metaophiolites, by glaucophane, garnet, and omphacite $[116,117,129]$ and a heterogeneous retrogression under blueschist-greenschists facies conditions. Metasediments the eclogite facies imprint is documented by phengite, garnet, and (now pseudomorphed) lawsonite [117].

\subsubsection{The Miserin Lake Section}

This study area is located in the southern sector of the Aosta valley (see location in Figure 2) and is mainly exposed in the high Champorcher valley, near lake Miserin. The Miserin lake metaophiolites consist of serpentinite + veined serpentinite overlain by a composite chaotic rock unit $[107,130]$. A calc schist unit directly overlies the chaotic rock unit or, where this latter is absent, the serpentinite basement. The contact between serpentinite or veined serpentinite and the chaotic unit is underlined by a more or less continuous layer, centimeters- to meters-thick, consisting of amphibole + carbonates-rich metasomatic rocks [131]. Serpentinites occur as thin slices of foliated rocks consisting of antigorite and oxides ( $\mathrm{Cr}$-Ni-rich magnetite, ilmenite, chromite). These rocks can be correlated with serpentinites of the nearby Mount Avic massif, which include, in addition to antigorite and oxides, Ti-clinohumite, relict augite, and diopside [71,73]. Serpentinites often grade towards veined serpentinites characterized by sets of veins $1-2 \mathrm{~cm}$ thick filled with carbonates, antigorite, or talc (Figure 8A). The veined serpentinite (or ophicarbonate) is overlain by a wedge-shaped composite chaotic unit, with a ca. $40 \mathrm{~m}$ maximum thickness, which represents the Alpine tectonic reworking and boudinage of primary mass transport deposits with a block-in-matrix arrangement and coarse-grained ultramafic sandstone alternating with marble layers. The block-in-matrix arrangement mainly consists of clastsupported metabreccias ("BrFm1" and "BrFm2" of Tartarotti et al. [107] (Figure S1). The 
metabreccia gradually passes upward into a chaotic rock unit ("sedimentary mélange" of Tartarotti et al. [107]), which consists of serpentinite and ophicarbonate blocks, up to meters wide, in a carbonate (now marble) matrix. This marble is unconformably overlain by a calc schist unit with a layered fabric due to carbonate-rich beds alternating with micaceous beds rich in garnet and chloritoid (Figure 8D). These calc schists are generally avoid of ophiolitic material, although in the nearby areas they include tectonic slices of micaceous quartzites and metabasalt.

\subsection{The Soana Valley Section across the Piemonte-Aosta Valley Border}

The Soana valley (Italian Graian Alps) is a lateral tributary of the Orco valley, located in the Piemonte region; it borders with the Aosta Valley to the north in the CogneChamporcher area. The upper Soana valley, similar to the Cogne-Champorcher area, is characterized by a stack of metaophiolite and continental basement units involved in the Alpine collisional belt. From bottom to top, the nappe pile includes: The Upper Penninic Gran Paradiso basement, the Piedmont Zone including slices of metaophiolites with metasediments, the Austroalpine Santanel klippe, and the Sesia-Lanzo Zone of continental origin. The structural setting of the Soana valley suggests an early-Alpine coupling of continental and oceanic units within the subduction zone followed by post-peak exhumation and folding under greenschist facies conditions. The complex structural setting and the various extent of rock re-equilibration during exhumation are mirrored by the imbrication of eclogitic and non-eclogitic units. This nappe stack has been then deformed by post-nappe folding during the mid-Tertiary [132].

The eclogite facies metaophiolite units consist of antigorite-Ti-clinohumite-bearing serpentinites, Mg- and Fe-Ti metagabbros, sometimes with relict igneous textures, and finegrained metabasalts, with the latter often retrogressed under greenschists facies conditions. Serpentinites make up lenticular slices of foliated or massive rocks that, in the Campiglia valley (western branch of the Soana valley), are a few hundred meters thick and include eclogitic metagabbro and metabasalt bodies. In the eastern branch of the Soana valley (i.e., the Piamprato Soana valley) the eclogite facies metaophiolites consist of predominant glaucophane, garnet-bearing metabasites and omphacite, garnet, glaucophane, rutilebearing Fe-Ti metagabbros and $\mathrm{Mg}$-metagabbro. This latter structural setting defined by mega-boudins of metagabbro wrapped by serpentinites is recurring in this area (i.e., Mt. Nero massif); it also recalls the one described in the Urtier valley where the eclogitic Pointe Noire Fe-Ti is wrapped by serpentinites.

Metasediments associated to the metaophiolites of the eclogitic units (Campiglia valley) consist of thin layers of garnet-bearing micaceous quartzites, chloritoid-garnet-bearing phyllites, and lawsonite-bearing calc schists. This sequence has a total thickness of a few hundred meters, although distorted by multiple folding effect. In the Piamprato Soana valley, metasediments are more abundant and represented by several types of rocks: Garnet, white mica-bearing quartzites often bearing Mn-rich minerals (piemontite, spessartine, \pm alurgite), which give the rock a pink-violet color (Figure 8E); garnet, chloritoid-bearing phyllites and micaschists; dark carbonate-rich calc schist; qtz-rich calc schists; garnetbearing chlorite- schists and calc schists. These latter are characterized, as in most calc schists outcrops of the Cogne-Urtier-Champorcher area, by a recurring compositional layering defined by marble layers alternating with micaceous layers bearing evident pseudomorphs on lawsonite (Figure $8 \mathrm{~F}$ ). Chlorite schists are locally associated with sulphide mineralization [133].

Most metasediments exposed in the Piamprato Soana valley have been attributed to a blueschist-to-greenschist facies unit [132] for not showing HP mineral assemblages and are not considered in this paper. Nevertheless, we cannot exclude that these rock units (mostly made of carbonate-rich calc schists; quartz-rich calc schists; chlorite, white mica-bearing calc schists, phyllites and micaschists, and $\mathrm{cm}$-thick layers of quartzites) result from pervasive re-equilibration of HP rocks under greenschist facies conditions. 
Summing up, the metasedimentary sequence of the Soana valley metaophiolite is comparable to the one described in the St. Marcel valley metaophiolites.
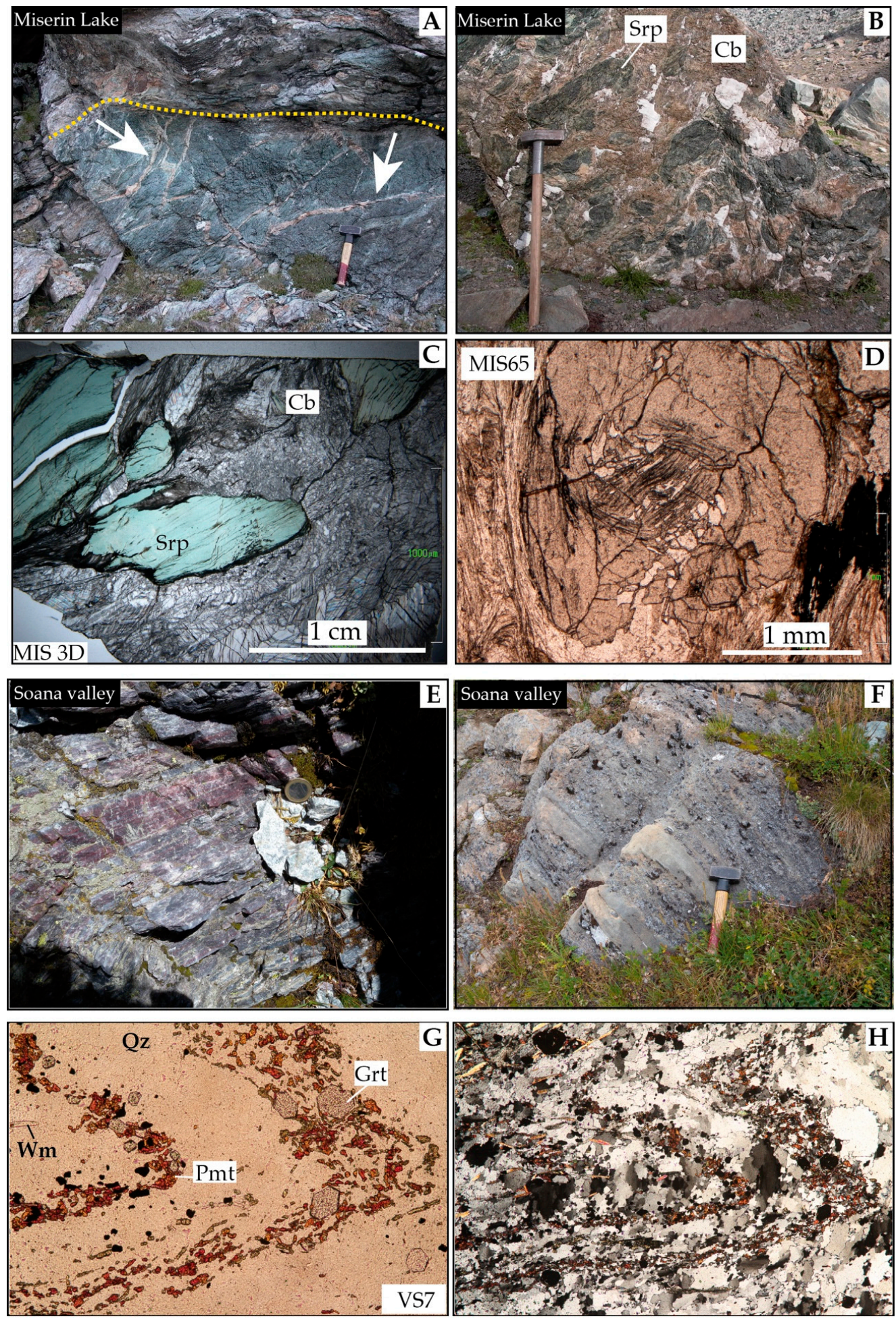

Figure 8. General views and photomicrographs of the Miserin lake and Soana valley sequences. (A) Miserin lake area (high Champorcher valley): Veined serpentinites with various sets of veins, 1-2 cm thick, filled with carbonate, antigorite, or talc. Hammer for scale. (B) Serpentinite (Srp) clasts and blocks enclosed in a carbonate-rich impure matrix (Cb) (hammer as scale; length ca. $70 \mathrm{~cm}$ ). (C) Miserin lake area: Photomicrograph of serpentinite metabreccia with carbonate-rich matrix; plane polarized light (sample MIS 3D). (D) Miserin lake area: Detail of zoned garnet in micaceous layers within calc schist; 
plane polarized light (sample MIS65). (E) Soana valley (high Piamprato Soana valley, near the Mt. Nero peak): foliated quartzites with Mn-rich minerals (piemontite, spessartine) giving the rock a pink-violet color. (F) Soana valley (Piamprato Soana valley) outcrop view of calc schists with typical compositional layering defined by marble layers alternating with micaceous layers bearing evident pseudomorphs on lawsonite. (G) Photomicrograph of Mn-rich quartzite from the high Soana valley (see Figure $8 \mathrm{E}$ for outcrop view). Layering defined by garnet+piemontite (Pmt) lithons alternating with quartz + white mica lithons; plane polarized light (sample VS7). (H) Same as (G) under crossed nicols (sample VS7; magnification: $10 \times$ ). Mineral abbreviations according to Whitney and Evans [128] except for white mica (Wm).

\subsection{Metasediments and Metaophiolites in the Monviso Massif}

The Monviso Massif is a well-preserved composite ophiolite nappe (i.e., the Monviso Complex), N-S trending, located in the southwestern part of the Alpine belt (Figures 1 and 3) and crosscut by the Varaita, Po and Pellice valleys from south to north, respectively [134]. The metaophiolite sequence was metamorphosed under eclogite facies conditions; it consists of serpentinite, metagabbro, talc schist, metabasalt, and metasedimentary rocks. The massive serpentinite is mainly made of antigorite and magnetite, with rare strongly deformed porphyroclasts of clinopyroxene and orthopyroxene, and textural relics of spinel and olivine. Locally preserved lizardite with mesh structure suggests primary ocean-floor serpentinization. At the uppermost part of the serpentinite, both massive and sheared metaophicarbonate locally occur. The latter consists of irregular calcite and dolomite vein networks that lace around centimeter to decimeter 'clasts' of serpentinite. The serpentinite hosts bodies of $\mathrm{Mg}$ - and Al-rich and minor Fe- and Ti-rich metagabbros, ranging in size from dykes of decimeters thickness to bodies of hundreds of meters thickness and sub-kilometer length. Contacts between the massive serpentinite and metagabbro are marked by rodingitic reaction rinds. Locally, the lack of pervasive Alpine metamorphic overprint [135] indicates that the rodingite-forming metasomatic event started as part of an in situ oceanic serpentinization process. The overlying talc schist and serpentine schist (i.e., the Baracun Shear Zone), are up to a few tens of meters in thickness and include blocks of Fe- and Ti-rich metagabbro of decimeters to meters in length $[12,136]$. Unlike the metagabbro bodies within the massive serpentinite, this metagabbro is devoid of rodingitic reaction rims, indicating that their emplacement must have occurred after the main phase of intra-oceanic serpentinization of the upper mantle peridotites [52].

The massive serpentinite and metagabbros, and the serpentine schist- and talc schistbearing shear zone, are discontinuously overlain by metabasalt and by different types of metasediment. The metabasalt ranges in thickness from tens of meters to several hundreds of meters, and includes fine-grained aphyric metabasalt, pillow metalavas (up to $1 \mathrm{~m}$ in size), and volcanic metabreccia. The metasediments discontinuously occur throughout the Monviso Complex and are up to a few hundred meters thick. They mainly consist of two different types of successions, which basically differ for the occurrence or absence of ophiolite-derived detrital material, according to the tectono-sedimentary environment of their deposition (i.e., the Late Jurassic syn-extensional succession and the Cretaceous post-extensional succession, respectively [52].

The first type of succession originally deposited above mantle rocks exhumed on the seafloor (serpentinized peridotite with gabbro bodies and rocks of the detachment-related Baracun shear zone) and was laterally interfingered with basaltic lavas [12]. It mainly consists of calc schist containing ophiolite-derived material and calc schist interbedded by mafic metasandstone horizons, up to decimeters in thickness (Figure 9A). Locally, bodies of metabreccia of gabbroic composition, up to a few meters in thickness, also occur. The calc schist is medium-grained and mainly made up of carbonate minerals (i.e., calcite, minor dolomite and ankerite), quartz, and white mica, with subordinate chloritoid, zoisite, and centimeter-sized aggregates of white mica, zoisite and graphite on post-lawsonite pseudomorphs (Figure 9B). Detrital ophiolitic material is represented by abundant $\mathrm{Mg}$ rich chlorite, relics of chromite crystals rimmed by $\mathrm{Cr}$-rich white mica, and magnetite pseudomorphs after spinel (Figure 9C). The mafic metasandstone and metabreccia are made of angular to poorly rounded grains and up to several centimeter-sized clasts. The 
latter consists of omphacite and aggregates of chlorite, Cr-rich white mica, and epidote, and are embedded in a groundmass of zoisite, amphibole, pistacite, albite, chlorite, quartz, and white mica [61].
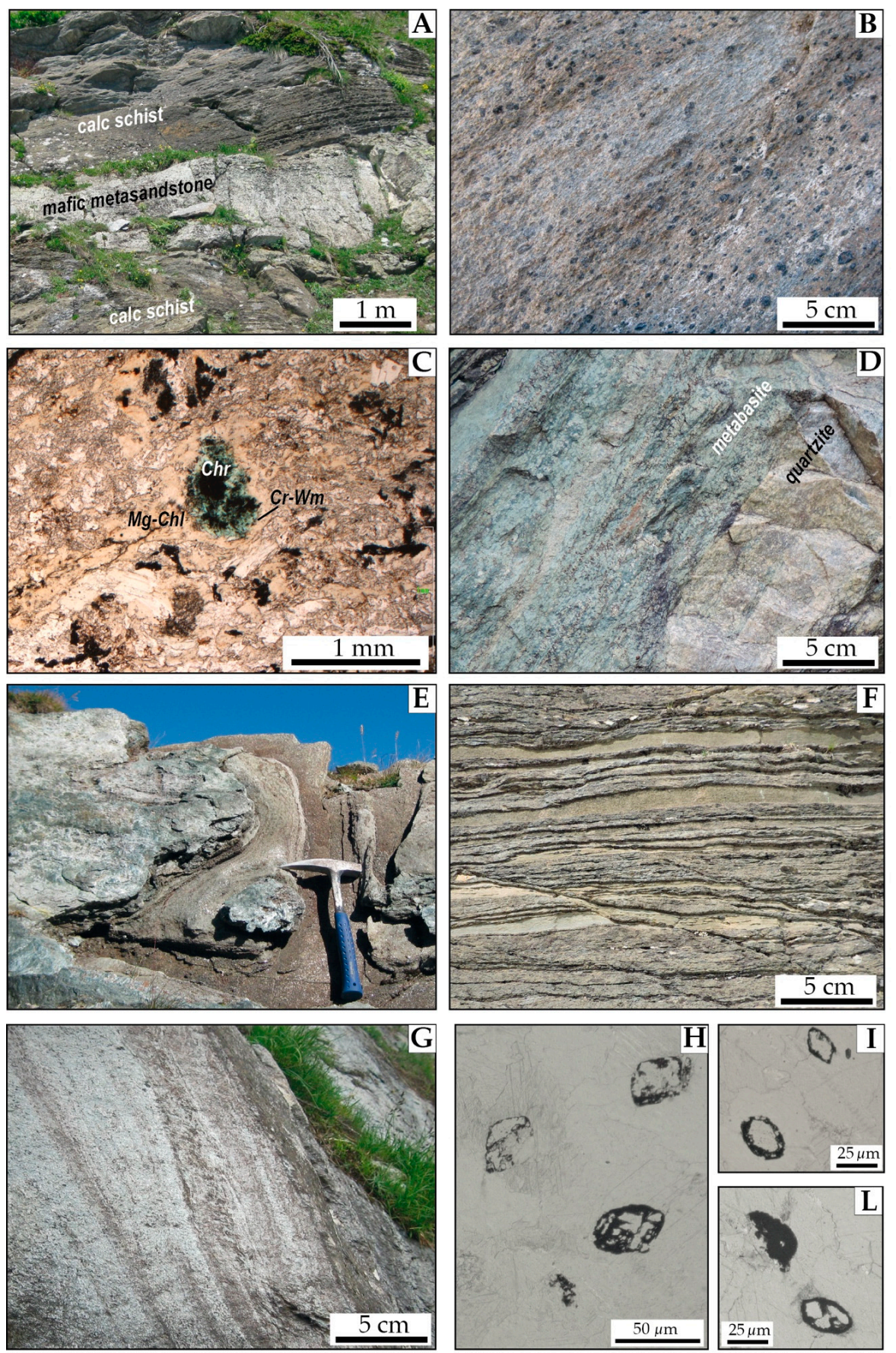

Figure 9. Field images and photomicrographs of metasediments from the Monviso ophiolite (Colle del Baracun area). (A) Calc schist interbedded by a layer of mafic metasandstone. (B) Close-up view of a calc schist with black aggregates on post-lawsonite pseudomorphs. (C) Thin section image of a calc schist including chromite crystals (Chr) rimmed by Cr-rich white mica (Cr-Wm) and Mg-rich chlorite (Mg-Chl); crossed nicols. (D) Close-up view of the contact between metabasite derived from a basaltic breccia and a horizon of quartzite. (E) Overturned contact between mafic metasandstone and marble. (F) close-up view of calc schist with layers of marble. (G) Calc schist with horizons of with quartz-schist. (H), (I), and (L) thin section images of calc schist including aggregates of calcite and Fe-oxide likely replacing planktonic Foraminifera; plane polarized light. 
The second type of succession consists of quartzite, marble, and calc schist that originally sealed the intra-oceanic seafloor architecture of the Monviso ophiolite. In different sectors of the Monviso Complex, they show stratigraphic contacts above serpentinite, metagabbro, rocks of the Baracun Shear Zone, and the first type succession (calc schists and metabasalt) [103]. The quartzite derives from chert or radiolarite, and marks the transition from the syn-extensional succession and the post-extensional one. It discontinuously occurs as centimeters- to decimeters-thick horizons, which are interbedded at the top of basaltic metabreccia or stratigraphically rest above metabasalt (Figure 9D) [62]. The quartzite is fine-grained and mainly made up of quartz and white mica, with minor garnet, $\mathrm{Mg}$-Fe chlorite, pistacite, amphibole, and $\mathrm{Mn}$-rich calcite. In a narrow sense, the very bottom of the second type succession is represented by decimeters-thick beds of withe or yellow marble (Figure 9E). The latter closely resembles the Upper Jurassic-Lower Cretaceous Calpionella Limestone of the non-metamorphosed cover of the Internal Ligurian ophiolites in the Northern Apennines $[137,138]$. The marble is fine-grained and mainly consists of calcite, with minor white mica, quartz, zoisite, and chlorite. The quartzite and marble horizons are stratigraphically overlain by tens of meters thick calc schist, the most widespread rock variety in this succession of the Monviso Complex. This calc schist, devoid of any ophiolite-derived detrital material, is typically interbedded by centimetersto decimeters-thick layers of marble (Figure 9F) [12]. It is fine- to medium-grained and made up of carbonate minerals (calcite, and minor dolomite and ankerite), quartz, and white mica, with subordinate chloritoid, Mg-Fe chlorite, and zoisite. Locally, the calc schist is also interbedded by several centimetres-thick layers of quartz-schist made up of quartz, white mica, and chlorite with minor albite and garnet (Figure 9G). This latter quartz schist probably derives from terrigenous sandstone occurred into mixed siliciclastic-carbonate turbidites, which filled the ocean basin. Remarkably, the calc schist is rarely characterized by occurrence of sub-millimeter aggregates of calcite and Fe-oxide, which closely resemble the outline of planktonic Foraminifera sections (Figure 9H). Similar aggregates have been detected in calc schist in the Western Alps [139,140] and Corsica [141], and they have been overall referred to the Albian-Cenomanian period.

\section{Discussion}

The Alpine metaophiolites are evidence of the sutured Jurassic Tethys Ocean that was interposed between the palaeo-European and palaeo-Adria continental plates. The Alpine metaophiolites have been involved in the orogenic cycle including subduction, collision, and exhumation. Consequently, part of them was probably removed, and part was exhumed and still remains within the Alpine orogenic wedge. They occur as dismembered and metamorphosed tectonic slices that rarely or never correspond to the idealized ophiolite suite defined by the Penrose conference [11]. In spite of the Alpine tectono-metamorphic reworking, some metaophiolites and their original sedimentary cover preserve records of their primary depositional setting and can be used for constraining the pre-orogenic evolution of the Jurassic Tethys Ocean.

The eclogite facies belt of the Western Alps, and particularly the metaophiolites exposed in the Aosta Valley and in the Monviso Complex, preserves textural and structural records of the pre-orogenic evolution, since it escaped the general structural reworking and recrystallisation during the exhumation and final stages of the Alpine convergent orogeny [142]. In fact, the occurrence of well-preserved HP mineral assemblages is likely due to the effect of deformation partitioning [143], acting since the inception of the Alpine subduction, which separated low-strained rock portions from high-strained ones. Highpressure metamorphic minerals and associated fabrics thus represent good markers for individuating low-strain domains that may preserve records of the primary intra-oceanic (pre-orogenic) architecture of the Tethyan depositional setting. Metasediments associated with ophiolites provide critical constraints to the reconstruction of the original depositional environment characterizing the Jurassic oceanic basin. This is well documented for ophiolites that were affected by low or very low-grade orogenic overprint, such as those 
exposed in the Northern Apennines [138]. In fact, it turned out that a comparative analysis of HP-metasedimentary sequences with analogue poorly deformed and recrystallized sections has been helpful for envisaging a possible scenario for the formation processes of the investigated successions $[12,107,116,137,138]$.

\subsection{Different "Tectono-Stratigraphic" Successions in the Western Alps}

Structural and lithostratigraphic field observations as well as petrographic and mineralogical data related to the eclogite facies internal belt of the Western Alps allow to identify three main different tectono-stratigraphic successions that likely represent different tectonosedimentary depositional environments and tectonic evolutionary steps. Nevertheless, we are aware that our inferences surely underestimate the huge information widespread at a regional scale.

The first type of tectono-stratigraphic succession (hereafter "type 1"; Monviso and Miserin lake areas; Figure 10) is identified for the occurrence of serpentinites and metagabbros associated with abundant detrital material of ophiolitic composition mixed or interbedded within metasediments. The ophiolite basement rocks of this succession consist of serpentinites made of serpentine (antigorite), Cr-Ni-rich magnetite, ilmenite, and chromite. Rare porphyroclasts of clinopyroxene and orthopyroxene, and textural relics of spinel and olivine were recognized, attesting the mantle nature of these serpentinites. The occurrence of lizardite with mesh structure suggests a possible record of primary ocean-floor serpentinization. Serpentinites grade to metaophicarbonates consisting of serpentinite crosscut by veins or vein networks filled with carbonates, antigorite, or talc. This mantle section may host gabbroic intrusions forming dykes or bodies, with or without metasomatic rinds, as observed in the Monviso Complex. Only in the Monviso Complex area, the serpentinite + metagabbro basement can be discontinuously overlain by metabasalt ranging in thickness from tens of meters to several hundreds of meters, also including volcanic metabreccia.

The metasedimentary cover sequence of the type 1 succession starts with ophicarbonate breccias ("type 1a") or with calc schist containing ophiolite-derived material and calc schist interbedded by mafic metasandstone horizons ("type $1 b^{\prime \prime}$ ). The ophicarbonate breccias of type 1a include both clast- and matrix-supported breccias, with block-in-matrix and/or sedimentary mélange-type internal fabrics (e.g., the chaotic rock unit of the Miserin lake series). The monotonous composition of clasts and the occurrence of $\mathrm{Cr}$-rich opaque minerals, reflect the ultramafic nature of the source feeding these breccias. In type $1 \mathrm{~b}$ succession (e.g., Monviso Complex), the detrital ophiolitic material is represented by $\mathrm{Mg}$-rich chlorite, relics of chromite crystals rimmed by $\mathrm{Cr}$-rich white mica, and magnetite pseudomorphs after spinel. However, a mafic component is also recorded and attested by the occurrence of metasandstones and metabreccias preserving omphacite (in the Monviso Complex area) and of clinopyroxenite clasts within calc schist (in the Cogne-Urtier area). Both type $1 \mathrm{a}$ and $1 \mathrm{~b}$ successions end with calc schists devoid of ophiolitic material, with a thickness ranging between a few meters to tens of meters; calc schists may include layers of marble and quartz-rich mica schists (Monviso and Miserin lake areas).

Therefore, the type 1 tectono-stratigraphic succession corresponds to a "reduced" succession where calc schists devoid of ophiolitic material unconformably overlain either mantle rocks or calc schists with detrital ophiolitic material, with no supra-ophiolitic covers (i.e., quartzite and marble) interposed. "Reduced" successions commonly characterize deposition along scarps of morphological or structural high reliefs within an articulated depositional environment. 


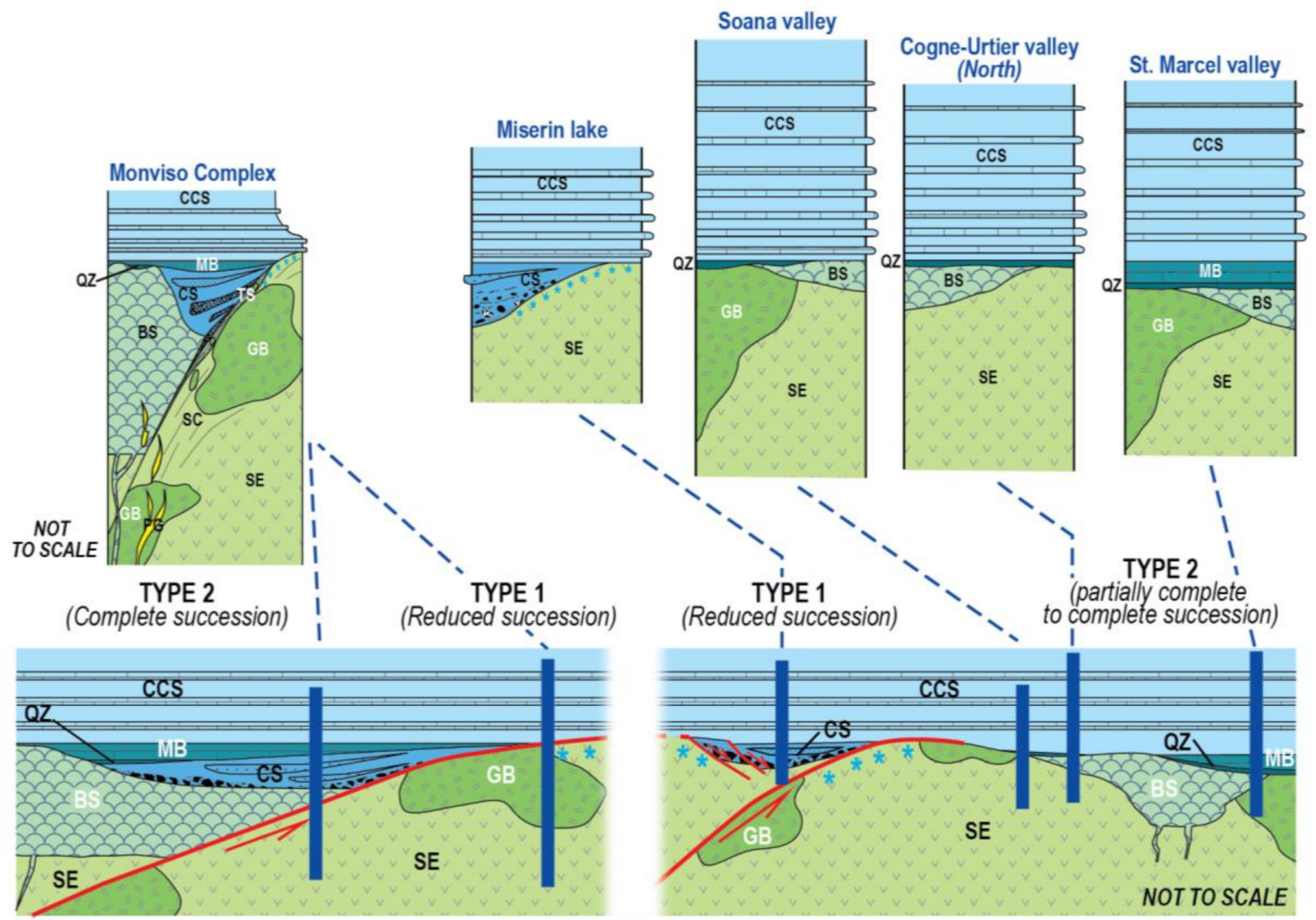

TYPE 3

(tectonic product)

Cogne-Urtier valley (South)

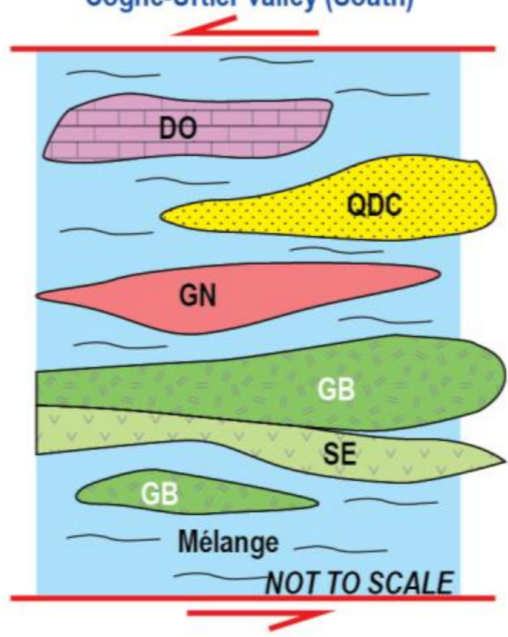

BS - metabasalt

CCS - calc schist alternating with marble layers

CS - calc schist with intercalations of mafic and/or ultramafic metasandstone and metabreccia

DO - metadolostone

GB - metagabbro

GN - gneiss, eclogite micaschist, amphibolite

$M B$ - marble

$P G$ - plagiogranite

QDC - quartzite, metadolostone, cargneule and carbonate breccia

$Q Z$ - quartzite

SC - serpentine schist

$S E$ - serpentinite, metaperidotite and metaophicarbonate (*)

TS - talcschist

Figure 10. Conceptual model illustrating interpretative reconstructions of the Jurassic Ligurian-Piedmont paleo-structure as deduced from the metasedimentary successions of the Aosta Valley and Monviso areas. The stratigraphic columnar sections of the studied areas (above) are tentatively projected to the inferred location within the reconstructed Jurassic ocean (middle). Type 3 section (below) represents the result of tectonic mixing between continental-derived and oceanic-derived units.

The second type of tectono-stratigraphic succession (hereafter "type 2"; Monviso Complex, St. Marcel and Soana valleys; Figure 10) consists of quartzite, marble, and calc schists devoid of ophiolitic material. These calc schists are well comparable with those described for the upper part of types $1 \mathrm{a}$ and $1 \mathrm{~b}$ successions. The type 2 cover succession 
can overly type $1 \mathrm{~b}$ successions or be in stratigraphic contact directly with serpentinite, metagabbro, or with the serpentine schist- and talc schist-bearing intra-oceanic extensional shear zones (e.g., the "Baracun shear zone" in the Monviso Complex) [52,103]. More often, this succession directly covers metamafic rocks, although the stratigraphic nature of the contact cannot be inferred certainly due to the occurrence, as in the St. Marcel valley, of actinolite schists underlying the contact between metaophiolite and quartzites and that could correspond to a tectonic contact. Summarizing, the type 2 tectono-stratigraphic succession may range from a "partially complete" succession (i.e., when it directly overlies mantle rocks) to a "complete" one (i.e., when it overlies type $1 \mathrm{~b}$ successions), consisting of all the stratigraphic terms that were originally deposited in a basinal environment.

The third type of tectono-stratigraphic succession (hereafter "type 3"; Cogne-Urtier area; Figure 10) is characterized by the strict association of carbonate- and dolomite-rich rocks, metaconglomerates, and evaporitic rocks (mainly "cargneule") with calc schists, quartzites rich in quartz porphyroclasts. This association is of tectonic origin and must not be confused with a primary succession. It formed through tectonic transposition as attested by the occurrence of relict fold hinges related to the Alpine $D_{1}-D_{2}$ phases, or to tectonic mixing as suggested by the presence of serpentinite slices interfingered within metasediments. Therefore, this tectono-stratigraphic unit or rock assemblage (i.e., the FDC) is particularly significant because it formed by the tectonic mixing of both rocks commonly interpreted as the sedimentary cover of thinned continental margins and ophiolite units [54,125].

\subsection{Pre-Orogenic Evolution of the Alpine Metaophiolites as Deduced from the Metasedimentary Successions}

Although subduction- to exhumation-related tectonic deformation and metamorphic recrystallisation partly obliterated the internal structure of the Tethyan oceanic lithosphere and the stratigraphic features of its cover successions, records of the primary tectonostratigraphic features can be recognized in several areas of the Western Alps, thus representing useful markers for unravelling the pre-orogenic evolution of the oceanic realm, and related passive continental margins. We used the tectono-stratigraphic successions defined above as markers to constrain various stages of the pre-Alpine history. The different characteristic and composition of those successions indicate that the emplacement of the oceanic lithosphere on the seafloor of the Jurassic Tethys oceanic basin was followed by various stages of sedimentation, often assisted by tectonics.

Syn-extensional stage. The occurrence of serpentinites, veined serpentinites, and metaophicarbonates, although partly attributable to the effect of Alpine carbonation of serpentinites $[107,130,131,144]$, attest for upper mantle exhumation during widespread extensional deformation that, at least locally, was favored by the development of a lithosphericscale detachment fault [12,52,103]. A record of this latter kind of structure has been identified in the Monviso Complex (i.e., the "Baracun Shear Zone") also producing a Late Jurassic oceanic core complex [52]. The upper mantle peridotites (now serpentinized) were intruded by gabbroic bodies and dykes probably before or during the emplacement of the mantle peridotite (i.e., the "main magmatic event" of Balestro et al. [12] now recognizable in the Monviso Complex and in the Aosta valley [72,73]. Subsequent magmatic events delivering basaltic lava flows account for the occurrence of metabasalts directly covering the serpentinized peridotites or gabbros, as in the Monviso area [12]. However, this stage of extensional tectonics during the opening of the Jurassic ocean was mostly characterized by the formation of ophiolitic breccias and mafic metasandstone as products of syn-tectonic sedimentation ranging from hyperconcentrated flows to turbidite currents (i.e., mass transport processes). In this context, type $1 \mathrm{a}$ and type $1 \mathrm{~b}$ successions are records of this syn-extensional stage (i.e., the "syn-extensional successions" of Balestro et al. [12,52] representing the lower part of "reduced" successions deposited along tectonic or morphological scarps of active structural or morphological high sectors within the oceanic basin. The deposition of breccias was triggered by the action of extensional faults, with or without concurrent volcanism. In the Aosta valley, detrital $\mathrm{Cr}$-rich minerals and serpentine clasts 
within carbonate-rich rocks are the key mineralogical evidence for this syn-extensional stage. Types $1 \mathrm{a}$ and $1 \mathrm{~b}$ successions are often directly covered by calc schists devoid of ophiolitic material (i.e., the same of the type 2 succession) that definitively sealed the syntectonic articulated morphology of the intra-oceanic basin (see below). All these features are consistent with a geodynamic setting close to a ridge axial valley or to a ridge-transform intersection (with or without oceanic core complex).

Post-extensional stage. The characteristics of type 2 tectono-stratigraphic succession, which consists of quartzites (from probable radiolarite), marble, and calc schists that are devoid of any intercalations of ophiolitic detrital material, are well comparable with those of the Tethyan ophiolites exposed in the non-metamorphosed Northern Apennine belt (i.e., radiolarian cherts, Calpionella Limestone, and Palombini Shales [138,145,146]. Similar to the Northern Apennines, the type 2 succession, was unconformably deposited on the articulated morphology of the oceanic basin, resulting from the lithospheric-scale extension associated to mantle exhumation (i.e., the syn-extensional stage). Therefore, type 2 succession can be interpreted as being post-extensional (i.e., the "post-extensional succession" of Balestro et al. [52]). The regional unconformity beneath this succession marks the temporal boundary between the lithospheric-scale extension and upper mantle exhumation (i.e., the syn-extensional stage) and a period of tectonic quiescence during which mainly pelagic deposition (i.e., type 2 succession) took place in and across the oceanic basin. Calc schists that are devoid of ophiolitic detrital material (i.e., calc schists of the uppermost types $1 \mathrm{a}$ and $1 \mathrm{~b}$ successions and type 2 succession), rest directly above all the different types of successions (i.e., from "reduced" to "complete") or above mantle rocks, varying from the ophiolitic breccias and/or chaotic units of the type 1 succession (e.g., Monviso Complex and Miserin Lake) to metamafic rocks that were likely delivered during a magma-dominated stage (e.g., St. Marcel and Soana valleys). The occurrence in the Monviso Complex of sub-millimeter aggregates of calcite and Fe-oxide, which closely resemble the outline of planktonic Foraminifera sections of Albian-Cenomanian age, also confirm that part of the calc schists of the type 2 succession are comparable in age with the middle-uppermost part of the Lower to early Upper Cretaceous Palombini shale of the Northern Apennines. Interestingly, in the St. Marcel and Soana valleys, the occurrence of $\mathrm{Cu}$-Fe sulphide mineralizations and a Mn-rich deposit interpreted as palaeo-hyrothermal fields of the Jurassic ocean $[108,109,133]$ suggests that type 2 successions of these valleys likely resemble a pelagic sequence sedimented not far away from hydrothermal vents [105]. These post-extensional successions are inferred to be consistent with the same geodynamic settings of that postulated for syn-extensional successions.

Type 3 succession represents a tectono-stratigraphic unit, likely derived from tectonic mixing or tectonic transposition of both oceanic and continental lithostratigraphic successions or tectonic slivers during the early stages of the Alpine convergence. The composition of the tectonic slivers, including carbonate- and dolomite-rich rocks, metaconglomerates and evaporitic rocks with calc schists, and quartzites rich in quartz porphyroclasts, suggest that this succession likely consisted of primary pre- to syn-rifting sediments deposited on the thinned passive continental margin. We thus cannot exclude that the Cogne-Urtier tectono-stratigraphic rock assemblage at least in part was formed near an ocean-continent transition (i.e., OCT) environment.

This tectonic mixing includes serpentinites and troctolites hosting a magnetite mineralization of hydrothermal origin. The age of ca. 150 Ma obtained for this magnetite mineralization near Cogne constrains its origin to an advanced stage of the Tethys opening associated to hydrothermal activity.

For type 3 tectono-stratigraphic unit, the identification of garnet within the regional $\mathrm{HP}$ foliation in metasediments from the Cogne-Urtier valley area supports the hypothesis that this tectonic mixing occurred during the Alpine subduction. 


\subsection{Constraints for the Pre-Alpine and Alpine Evolution}

Vertical facies variations in the meta-sedimentary successions investigated in the eclogite facies internal belt of the Western Alps and their mineralogy provide important clues for deciphering the physiography of the Jurassic Tethys ocean and its evolution during the Alpine convergence (Figure 10). The syn-extensional sedimentary successions (types $1 \mathrm{a}$ and $1 \mathrm{~b}$ ) are identified for their abundance of ophiolitic breccias directly covering the serpentinites (ophicarbonate breccias) or occurring as intercalations within finer-grained sediments. These successions are consistent with a rugged seafloor topography resulting from intense tectonics, likely related to the development of extensional or transform faults with scarce magma delivering. Oceanic core complexes and detachment faults are likely structures contributing to the shape of the Jurassic Tethys (Figure 10). All these features have been documented in modern slow- to ultraslow-spreading oceans [147-149] where sediments are often dominated by the occurrence of breccias [150,151]. Serpentinite breccias have been also documented near modern OCT, such as the Galicia margin [152-154], so we cannot exclude that part of the studied successions were emplaced not far away from the Tethys passive continental margins. The calc schists of both types 1 and type 2 successions found in the investigated areas of the Western Alps, likely deposited above both the "complete" (e.g., in the Monviso area, St. Marcel and Soana valleys) and the "reduced" successions, where the basal quartzites and marble are lacking (e.g., Miserin lake area). This evidence suggests that at the time of calc schists' deposition, the articulated syn-extensional seafloor physiography of the Tethyan Ocean floor was roughly flattened, allowing the deposition of distal turbidite system.

Finally, the type 3 tectono-stratigraphic unit, although most probably inherited from the Alpine tectonics acting since the inception of the convergence and subduction, represents clear evidence of the existence and involvement of a passive continental margin and its related sedimentary cover.

\subsection{Concluding Remarks}

The meta-sedimentary tectono-stratigraphic successions here analyzed belong to the Alpine metaophiolites deriving from the closure of the Jurassic Tethys Ocean. These successions have been involved in the subduction and collision processes responsible for the formation of the Alpine orogenic belt, as attested by the occurrence of well-preserved eclogite facies mineral assemblages, partly re-equilibrated under greenschist facies conditions. In spite of the severe Alpine reworking, these successions are among the best-preserved examples ever found in the Western Alpine metaophiolites. They provide useful tools for deciphering their original setting and the pre-orogenic evolution of the Jurassic Tethys. Three main types of tectono-stratigraphic successions were identified in the Aosta Valley region and in the Monviso area (Piemonte region):

1. Type 1 succession has an ophiolite basement composed of serpentinite, ophicarbonate, and metagabbros covered by a metasedimentary cover rich in ultramafic and mafic breccias and detrital material sealed on top by calc schists devoid of ophiolitic material. Its lower part (i.e., types $1 \mathrm{a}$ and $1 \mathrm{~b}$ ), below calc schists, is inferred to represent a "reduced" succession deposited along morphological or structural scarps of high reliefs, developed during the syn-extensional stage of the Jurassic Tethys Ocean leading to upper mantle exhumation favored by the development of a lithosphericscale detachment fault.

2. Type 2 succession consists of quartzite, marble, and calc schists that are devoid of ophiolitic material intercalations. This cover succession can be in stratigraphic contact above both types $1 \mathrm{a}$ and $1 \mathrm{~b}$ successions or on mantle rocks. It is interpreted as a "partially complete "to "complete" succession, unconformably deposited on the articulated morphology of the oceanic basin during the post-extensional stage, possibly not far away from hydrothermal vents.

3. Type 3 succession is characterized by the strict association of carbonate- and dolomiterich rocks alternating with metaconglomerate, evaporitic rocks (mainly "cargneule"), 
calc schists, quartzites, and serpentinite slivers. This rock association is interpreted as deriving by tectonic transposition of both continent-derived and ocean-derived lithologies during the early Alpine ductile deformation phases. Although tectonically mixed, these rocks are attributable to an original ocean-continent-transition (OCT) zone.

Finally, the ophiolite-free calc schist sedimentation sealing the metasedimentary successions suggests that at the time of calc schists' deposition, the articulated syn-extensional seafloor physiography of the Tethyan Ocean floor was roughly flattened, allowing deposition of distal turbidite system.

\subsection{Future Perspectives}

A comparative analysis of the Western Alpine metaophiolite metasedimentary covers, with the sedimentary sequences of poorly deformed and metamorphosed orogenic belts such as the Apennine chain, would be useful to better identify their original counterparts. However, among the tectono-stratigraphic successions here investigated, only type 2 succession is comparable to the radiolarian cherts-Calpionella Limestone-Palombini Shales series of the Northern Apennines, dated as Middle Jurassic-Early Upper Cretaceous.

In all the studied areas, there is no clear evidence of successions comparable with the classical Late Cretaceous (i.e., Maastrichtian)-Paleocene flysch succession (e.g., Helmintoides flysch Auct.) or with the Late Cretaceous (Santonian-Campanian) sedimentary mélanges with blocks and olistoliths of mantle rocks and supra-ophiolitic covers (e.g., Casanova Complex Auct.) observed in the non- to low-grade metamorphic units of Alpine-Apennine system (i.e., Internal and External Ligurian Units of the Northern Appennines, and Schistes Lustrés and Combin units in Western Alps). Several reasons could be invoked to address this issue among which: (i) No sediments analogue to those observed in the Northern Apennines were deposited; (ii) the Alpine subduction completely swallowed these sediments into deep mantle; (iii) they were accreted into the Alpine frontal wedge during convergent stages and thus early decoupled from the HP metaophiolite units. As future developments, further investigations should be carried out in more external units of the Western Alps characterized by huge volumes of calc schists s.l. englobing ophiolitic materials (e.g., Schistes Lustrés and Combin units) in order to address this issue.

A further topic of investigation regards the type 3 tectono-sedimentary unit, which is inferred to be the product of tectonic folding and transposition during the early stages of the Alpine evolution under HP metamorphic conditions. Its proximity to the continental Pennidic units may support the hypothesis of a tectonic mixing between oceanic and continental-derived slices during the convergent tectonics, possibly derived from a primary ocean-continent transition (OCT) zone. The challenge is now to quantify the contribute of convergent tectonics in juxtaposing and mixing continental and oceanic units with respect to a primary OCT zone, which already consisted of extensional continental allochtons above mantle rocks (i.e., definition of the hyper-extended margin physiography). This challenge should be tested in similar areas of the Western Alps close to the main contacts between oceanic and continental units (e.g., Monte Rosa, Dora Maira Penninic units), providing new essential constraints to better understand the evolution of Western Alps as well as the role played by the inherited pre-orogenic settings.

Supplementary Materials: The following are available online at https:/ /www.mdpi.com/article/10 $.3390 / \mathrm{min} 11040411 / \mathrm{s} 1$, Figure S1: Photomicrographs of the Cogne-Urtier sequences.

Author Contributions: P.T.: Conceptualization, data acquisition, interpretation of data, drawings, and writing. S.M.: Conceptualization and critically revising for important intellectual content; field data acquisition and interpretation. A.F.: Conceptualization, writing, drawings, and critically revising for important intellectual content. G.B.: Conceptualization, writing, and drawings. All authors have read and agreed to the published version of the manuscript. 
Funding: This research was funded by Università degli Studi di Milano, grant number PSR2019_ IBOLLATI, and Università degli Studi di Padova, grant number "Dotazione Ordinaria della Ricerca"DOR2020.

Acknowledgments: Two anonymous reviewers are kindly thanked for their critical reading and improving the manuscript.

Conflicts of Interest: The authors declare no conflict of interest. The funders had no role in the design of the study; in the collection, analyses, or interpretation of data; in the writing of the manuscript, or in the decision to publish the results.

\section{References}

1. Moores, E.M.; Kellogg, L.H.; Dilek, Y. Tethyan ophiolites, mantle convection, and tectonic "historical contingency": A resolution of the "ophiolite conundrum". In Ophiolites and Oceanic Crust: New Insights from Field Studies and the Ocean Drilling Program; Dilek, Y., Moores, E., Elthon, D., Nicolas, A., Eds.; Geological Society of America; Special Paper; Boulder, CO, USA, 2000; Volume 349, pp. 3-12.

2. Dilek, Y.; Flower, M.F.J. Arc-trench rollback and forearc accretion: 2. A model template for ophiolites in Albania, Cyprus, and Oman. Geol. Soc. Lond. Spec. Publ. 2003, 218, 43-68. [CrossRef]

3. Furnes, H.; Dilek, Y.; Zhao, G.; Safonova, I.; Santosh, M. Geochemical characterization of ophiolites in the Alpine-Himalayan Orogenic Belt: Magmatically and tectonically diverse evolution of the Mesozoic Neotethyan oceanic crust. Earth Sci. Rev. 2020, 208, 103258. [CrossRef]

4. Dilek, Y.; Furnes, H. Structure and geochemistry of Tethyan ophiolites and their petrogenesis in subduction rollback systems. Lithos 2009, 113, 1-20. [CrossRef]

5. Dilek, Y.; Furnes, H. Tethyan ophiolites and Tethyan seaways. J. Geol. Soc. 2019, 176, 899-912. [CrossRef]

6. Moores, E.M.; Vine, F.J. The Troodos Massif, Cyprus and other ophiolites as oceanic crust: Evaluation and implications. Philos. Trans. R. Soc. Lond. Ser. A Math. Phys. Sci. 1971, 268, 443-467. [CrossRef]

7. Dilek, Y.; Eddy, C.A. The Troodos (Cyprus) and Kizildag (S. Turkey) Ophiolites as Structural Models for Slow-Spreading Ridge Segments. J. Geol. 1992, 100, 305-322. [CrossRef]

8. Dewey, J.F.; Pitman, W.C., III; Ryan, W.B.F.; Bonnin, J. Plate Tectonics and the Evolution of the Alpine System. Geol. Soc. Am. Bull. 1973, 84, 3137-3180. [CrossRef]

9. Polino, R.; Dal Piaz, G.V.; Gosso, G. Tectonic erosion at the Adria margin and accretionary processes for the Cretaceous orogeny of the Alps. Mem. Soc. Geol. Fr. 1990, 156, 345-367.

10. Deville, E.; Fudral, S.; Lagabrielle, Y.; Marthaler, M.; Sartori, M. From oceanic closure to continental collision: A synthesis of the "Schistes lustrés" metamorphic complex of the Western Alps. GSA Bull. 1992, 104, 127-139. [CrossRef]

11. Anonymous. Penrose field conference on ophiolites. Geotimes 1972, 17, 24-25.

12. Balestro, G.; Festa, A.; Dilek, Y. Structural architecture of the Western Alpine Ophiolites, and the Jurassic seafloor spreading tectonics of the Alpine Tethys. J. Geol. Soc. 2019, 176, 913-930. [CrossRef]

13. Bearth, P.; Schwander, H. The post-Triassic sediments of the ophiolite zone Zermatt-Saas Fee and the associated manganese mineralizations. Eclogae Geol. Helv. 1981, 74, 189-205.

14. Dal Piaz, G.V.; Ernst, W.G. Areal geology and petrology of eclogites and associated metabasites of the Piemonte ophiolite nappe, breuil—St. Jacques area, Italian Western Alps. Tectonophysics 1978, 51, 99-126. [CrossRef]

15. Barnicoat, A.C.; Fry, N. High-pressure metamorphism of the Zermatt-Saas ophiolite zone, Switzerland. J. Geol. Soc. 1986, 143, 607-618. [CrossRef]

16. Bousquet, R.; Engi, M.; Gosso, G.; Oberhänsli, R.; Berger, A.; Spalla, M.I.; Goffé, B. Metamorphic structure of the Alps. In Explanatory Note to the Map "Metamorphic Structure of the Alps"; Commission for the Geological Map of the World: Paris, France, 2004.

17. Roure, F.; Heitzmann, P.; Polino, P. Deep Structure of the Alps; Soc. Géol. de France: Paris, France, 1990; Memoire N. 156.

18. Dal Piaz, G.V.; Bistacchi, A.; Massironi, M. Geological outline of the Alps. Episodes 2003, 26, 175-180. [CrossRef]

19. Handy, M.R.; Schmid, S.M.; Bousquet, R.; Kissling, E.; Bernoulli, D. Reconciling plate-tectonic reconstructions of Alpine Tethys with the geological-geophysical record of spreading and subduction in the Alps. Earth Sci. Rev. 2010, 102, 121-158. [CrossRef]

20. Argand, E. Des Alpes et de l'Afrique. Bul. Soc. Vaud. Sci. Nat. 1924, 55, 233-236.

21. Dal Piaz, G.V. History of tectonic interpretations of the Alps. J. Geodyn. 2001, 32, 99-114. [CrossRef]

22. Loprieno, A.; Bousquet, R.; Bucher, S.; Ceriani, S.; Torre, F.H.D.; Fügenschuh, B.; Schmid, S.M. The Valais units in Savoy (France): A key area for understanding the palaeogeography and the tectonic evolution of the Western Alps. Acta Diabetol. 2010, 100, 963-992. [CrossRef]

23. Stampfli, G.; Mosar, J.; Marquer, D.; Marchant, R.; Baudin, T.; Borel, G. Subduction and obduction processes in the Swiss Alps. Tectonophysics 1998, 296, 159-204. [CrossRef]

24. Schmid, S.M.; Fügenschuh, B.; Kissling, E.; Schuster, R. Tectonic map and overall architecture of the Alpine orogen. Swiss J. Geosci. 2004, 97, 93-117. [CrossRef]

25. Decarlis, A.; Dallagiovanna, G.; Lualdi, A.; Maino, M.; Seno, S. Stratigraphic evolution in the Ligurian Alps between Variscan heritages and the Alpine Tethys opening: A review. Earth Sci. Rev. 2013, 125, 43-68. [CrossRef] 
26. Ballèvre, M.; Manzotti, P.; Piaz, G.V.D. Pre-Alpine (Variscan) Inheritance: A Key for the Location of the Future Valaisan Basin (Western Alps). Tectonics 2018, 37, 786-817. [CrossRef]

27. Brouwer, F.M.; Burri, T.; Engi, M.; Berger, A. Eclogite relics in the Central Alps: PT-evolution, Lu-Hf ages and implications for formation of tectonic mlange zones. Schweiz. Mineral. Petrogr. Mitt. 2005, 85, 147-174.

28. Ernst, W.G.; Dal Piaz, G.V. Mineral parageneses of eclogitic rocks and related mafic schists of Piemonte ophiolite nappe, Breuil-St.Jacques Area, Italian Western Alps. Am. Mineral. 1978, 63, 621-640.

29. Reinecke, T. Prograde high- to ultrahigh-pressure metamorphism and exhumation of oceanic sediments at Lago di Cignana, Zermatt-Saas Zone, western Alps. Lithos 1998, 42, 147-189. [CrossRef]

30. Bucher, K.; Fazis, Y.; De Capitani, C.; Grapes, R. Blueschists, eclogites, and decompression assemblages of the Zermatt-Saas ophiolite: High-pressure metamorphism of subducted Tethys lithosphere. Am. Miner. 2005, 90, 821-835. [CrossRef]

31. Angiboust, S.; Agard, P.; Jolivet, L.; Beyssac, O. The Zermatt-Saas ophiolite: The largest (60-km wide) and deepest (c.70-80 km) continuous slice of oceanic lithosphere detached from a subduction zone? Terra Nova 2009, 21, 171-180. [CrossRef]

32. Groppo, C.; Beltrando, M.; Compagnoni, R. TheP-Tpath of the ultra-high pressure Lago Di Cignana and adjoining high-pressure meta-ophiolitic units: Insights into the evolution of the subducting Tethyan slab. J. Metamorph. Geol. 2009, 27, 207-231. [CrossRef]

33. Frezzotti, M.L.; Selverstone, J.; Sharp, Z.D.; Compagnoni, R. Carbonate dissolution during subduction revealed by diamondbearing rocks from the Alps. Nat. Geosci. 2011, 4, 703-706. [CrossRef]

34. Luoni, P.; Rebay, G.; Spalla, M.I.; Zanoni, D. UHP Ti-chondrodite in the Zermatt-Saas serpentinite: Constraints on a new tectonic scenario. Am. Miner. 2018, 103, 1002-1005. [CrossRef]

35. Caron, J.M. Relation entre métamorphisme et déformation dans les Alpes cotienne. Eclogae Geol. Helv. 1979, 72, $497-507$.

36. Tricart, P.; Schwartz, S. A north-south section across the Queyras Schistes lustrés (Piedmont zone, Western Alps): Syn-collision refolding of a subduction wedge. Swiss J. Geosci. 2006, 99, 429-442. [CrossRef]

37. Goffé, B.; Schwartz, S.; Lardeaux, J.M.; Bousquet, R. Explanatory notes to the map: Metamorphic structure of the western and ligurian Alps. Mitt. Osterr. Mineral. Ges. 2004, 149, 125-144.

38. Schwartz, S. La zone piémontaise des Alpes occidentales: Un paléocomplexe de subduction. Arguments métamorphiques, géochronologiques et structuraux. Doc. Bur. Rech. Geol. Min. Orleans 2002, 302, 313.

39. Agard, P.; Jolivet, L.; Goffe, B. Tectonometamorphic evolution of the Schistes Lustres Complex; implications for the exhumation of HP and UHP rocks in the Western Alps. Bull. Soc. Geol. Fr. 2001, 172, 617-636. [CrossRef]

40. Agard, P.; Monie, P.; Jolivet, L.; Goffe, B. Exhumation of the Schistes Lustres complex: In situ laser probe 40Ar/39Ar constraints and implications for the Western Alps. J. Metamorph. Geol. 2002, 20, 599-618. [CrossRef]

41. Bousquet, R.; Oberhänsli, R.; Goffé, B.; Wiederkehr, M.; Koller, F.; Schmid, S.M.; Schuster, R.; Engi, M.; Berger, A.; Martinotti, G. Metamorphism of metasediments at the scale of an orogen: A key to the Tertiary geodynamic evolution of the Alps. Geol. Soc. Lond. Spec. Publ. 2008, 298, 393-411. [CrossRef]

42. Dal Piaz, G.; Cortiana, G.; Del Moro, A.; Martin, S.; Pennacchioni, G.; Tartarotti, P. Tertiary age and paleostructural inferences of the eclogitic imprint in the Austroalpine outliers and Zermatt-Saas ophiolite, western Alps. Acta Diabetol. 2001, 90, 668-684. [CrossRef]

43. Manzotti, P.; Bosse, V.; Pitra, P.; Robyr, M.; Schiavi, F.; Ballevre, M. Exhumation rates in the Gran Paradiso Massif (Western Alps) constrained by in situ $\mathrm{U}-\mathrm{Th}-\mathrm{Pb}$ dating of accessory phases (monazite, allanite and xenotime). Contrib. Miner. Pet. 2018, 173, 24 [CrossRef]

44. Rebay, G.; Zanoni, D.; Langone, A.; Luoni, P.; Tiepolo, M.; Spalla, M.I. Dating of ultramafic rocks from the Western Alps ophiolites discloses Late Cretaceous subduction ages in the Zermatt-Saas Zone. Geol. Mag. 2018, 155, 298-315. [CrossRef]

45. Rubatto, D.; Regis, D.; Hermann, J.; Boston, K.; Engi, M.; Beltrando, M.; McAlpine, S.R.B. Yo-yo subduction recorded by accessory minerals in the Italian Western Alps. Nat. Geosci. 2011, 4, 338-342. [CrossRef]

46. Reddy, S.M.; Wheeler, J.; Cliff, R.A. The geometry and timing of orogenic extension: An example from the Western Italian Alps. J. Metamorph. Geol. 1999, 17, 573-589. [CrossRef]

47. Beltrando, M.; Lister, G.S.; Forster, M.; Dunlap, W.J.; Fraser, G.; Hermann, J.; Hermann, J. Dating microstructures by the 40Ar/39Ar step-heating technique: Deformation-pressure-temperature-time history of the Penninic Units of the Western Alps. Lithos 2009, 113, 801-819. [CrossRef]

48. Skora, S.; Mahlen, N.J.; Johnson, C.M.; Baumgartner, L.P.; Lapen, T.J.; Beard, B.L.; Szilvagyi, E.T. Evidence for protracted prograde metamorphism followed by rapid exhumation of the Zermatt-Saas Fee ophiolite. J. Metamorph. Geol. 2015, 33, 711-734. [CrossRef]

49. Gouzu, C.; Yagi, K.; Thanh, N.X.; Itaya, T.; Compagnoni, R. White mica K-Ar geochronology of HP-UHP units in the Lago di Cignana area, western Alps, Italy: Tectonic implications for exhumation. Lithos 2016, 248-251, 109-118. [CrossRef]

50. Schmid, S.; Zingg, A.; Handy, M. The kinematics of movements along the Insubric Line and the emplacement of the Ivrea Zone. Tectonophysics 1987, 135, 47-66. [CrossRef]

51. Festa, A.; Balestro, G.; Borghi, A.; De Caroli, S.; Succo, A. The role of structural inheritance in continental break-up and exhumation of Alpine Tethyan mantle (Canavese Zone, Western Alps). Geosci. Front. 2020, 11, 167-188. [CrossRef]

52. Balestro, G.; Festa, A.; Dilek, Y.; Tartarotti, P. Pre-Alpine extensional tectonics of a peridotite localized core complex in the Late Jurassic, high-pressure Monviso ophiolite (Western Alps). Episodes 2015, 38, 266-282. [CrossRef]

53. Festa, A.; Ogata, K.; Pini, G.A.; Dilek, Y.; Alonso, J.L. Origin and significance of olistostromes in the evolution of orogenic belts: A global synthesis. Gondwana Res. 2016, 39, 180-203. [CrossRef] 
54. Elter, G. Schistes lustrés et ophiolites de la zone piémontaise entre Orco et Doire Baltée (Alpes Graies). Hypothèses sur l'origine des ophiolites. Géologie Alp. 1971, 47, 147-169.

55. Laubscher, H.P. The large-scale kinematics of the western Alps and the northern Apennines and its palinspastic implications. Am. J. Sci. 1971, 271, 193-226. [CrossRef]

56. Martin, S.; Tartarotti, P.; Dal Piaz, G.V. The Mesozoic ophiolites of the Alps: A review. Boll. Geof. Teor. Appl. 1994, 36, 141-144, 175-220.

57. Bearth, P. Die Ophiolithe der Zone Von Zermatt-Saas Fee, Mat; Carte Géologique Suisse; Kümmerly \& Frey: Bern, Switzerland, 1967; p. 132.

58. Dal Piaz, G.V. La formazione mesozoica dei calcescisti con pietre verdi fra la Valsesia e la Valtournanche ed i suoi rapporti strutturali con il ricoprimento Monte Rosa e con la zona Sesia-Lanzo. Boll. Soc. Geol. Ital. 1965, 84, n.1.

59. Dal Piaz, G.V. Le métamorphisme de haute pression et basse température dans l'evolution structurale du bassin ophiolitique alpino-apenninique. Boll. Soc. Geol. Ital. 1974, 54, 399-424.

60. Ballèvre, M.; Merle, O. The Combin fault: Compressional reactivation of a Late Cretaceous-Early Tertiary detachment fault in the Western Alps. Schweiz. Mineral. Petrogr. Mitt. 1993, 73, 205-227.

61. Balestro, G.; Festa, A.; Borghi, A.; Castelli, D.; Gattiglio, M.; Tartarotti, P. Role of Late Jurassic intra-oceanic structural inheritance in the Alpine tectonic evolution of the Monviso meta-ophiolite Complex (Western Alps). Geol. Mag. 2017, 155, 233-249. [CrossRef]

62. Lombardo, B.; Nervo, R.; Compagnoni, R.; Messiga, B.; Kienast, J.-R.; Mevel, C.; Fiora, L.; Piccardo, G.; Lanza, R. Osservazioni preliminari sulle ofioliti metamorfiche del Monviso (Alpi Occidentali). Rend. Soc. Ital. Mineral. Petrol. 1978, 34, $253-305$.

63. Balestro, G.; Fioraso, G.; Lombardo, B. Geological map of the Monviso massif (Western Alps). J. Maps 2013, 9, 623-634. [CrossRef]

64. Pognante, U.; Kienast, J.-R. Blueschist and Eclogite transformations in Fe-Ti Gabbros: A Case from the Western Alps Ophiolites. J. Pet. 1987, 28, 271-292. [CrossRef]

65. Capponi, G.; Crispini, L.; Federico, L.; Malatesta, C. Geology of the Eastern Ligurian Alps: A review of the tectonic units. Ital. J. Geosci. 2016, 135, 157-169. [CrossRef]

66. Lagabrielle, Y. Ophiolites et Croûte Océanique, Tectonique et Environnement Sédimentaire: Apports des Données Sous-Marines à L'interprétation Géologique des Séries Ophiolitifères du Queyras (Alpes Franco-Italiennes). Ph.D. Thesis, Université de Bretagne Occidentale-Brest, Brest, France, 1982; 198p.

67. Lagabrielle, Y.; Brovarone, A.V.; Ildefonse, B. Fossil oceanic core complexes recognized in the blueschist metaophiolites of Western Alps and Corsica. Earth Sci. Rev. 2015, 141, 1-26. [CrossRef]

68. Tartarotti, P.; Martin, S.; Polino, R. Geological data about the ophiolitic sequences in the St. Marcel valley (Aosta Valley). Ofioliti 1986, 3, 343-346.

69. Martin, S.; Tartarotti, P. Polyphase HP metamorphism in the ophiolitic glaucophanites of the lower St. Marcel valley (Aosta valley). Ofioliti 1989, 14, 135-156.

70. Novo, M.; Accotto, S.; Nervo, R.; Pognante, U. Jadeite-quartz bearing metatrondhjemites from the Mt. Nero ophiolitic eclogites, Champorcher Valley (North-Western Alps). Ofioliti 1989, 14, 57-62.

71. Fontana, E.; Panseri, M.; Tartarotti, P. Oceanic textures in the Mount Avic serpentinites, Western Alps. Ofioliti 2008, 33, 105-118.

72. Panseri, M.; Fontana, E.; Tartarotti, P. Evolution of rodingitic dykes: Metasomatism and metamorphism in the Mount Avic serpentinites (Alpine ophiolites, southern Aosta Valley). Ofioliti 2008, 33, 165-185.

73. Fontana, E.; Tartarotti, P.; Panseri, M.; Buscemi, S. Geological map of the Mount Avic massif (Western Alps Ophiolites). J. Maps 2015, 11, 126-135. [CrossRef]

74. Baldelli, C.; Piaz, G.D.; Lombardo, B. Ophiolite eclogites from Verres, Val d'Aosta, Western Alps, Italy. Chem. Geol. 1985, 50, 87-98. [CrossRef]

75. Castelli, D. La Falda Piemontese alla base del margine sudoccidentale del lembo dell'Emilius, media Valle d'Aosta. Ofioliti 1985, 10, 19-34.

76. Martin, S.; Kienast, J.R. The HP-LT manganiferous quartzites of Praborna, Piemonte ophiolite nappe, Italian western Alps. Schweiz. Mineral. Petrogr. Mitt. 1987, 67, 339-360.

77. Benciolini, L.; Lombardo, B.; Martin, S. Mineral chemistry and Fe/Mg exchange geothermometry of ferrogabbro-derived eclogites from the Northwestern Alps. N. Jahrb. Mineral. Abh. 1988, 159, 199-222.

78. Angiboust, S.; Agard, P. Initial water budget: The key to detaching large volumes of eclogitized oceanic crust along the subduction channel? Lithos 2010, 120, 453-474. [CrossRef]

79. Dal Piaz, G.V.; Pennacchioni, G.; Tartarotti, P.; Carraro, F.; Gianotti, F.; Monopoli, B.; Schiavo, A. Carta Geologica d'Italia, Foglio Chatillon (Geological Map of Italy, Sheet Chatillon 2010, Roma ISPRA, Istituto Superiore per la Protezione e la Ricerca Ambientale. Available online: https:/ / www.isprambiente.gov.it/Media/carg/91_CHATILLON/Foglio.html (accessed on 5 March 2021).

80. Dal Piaz, G.V.; Lombardo, B.; Gosso, G. Metamorphic evolution of the Mt. Emilius klippe, Dent Blanche nappe, western Alps. Am. J. Sci. A 1983, 283, 438-458.

81. Paganelli, E.; Compagnoni, R.; Nervo, R.; Tallone, S. Il lembo Austroalpino di Eaux Rousses e le Sue Relazioni con la Zona Ofiolitica Piemontese Nell'alta Valle di Cogne, Valle d'Aosta Meridionale. In Atti Convegno Alpi-Appennino, Peveragno; Polino, R., Sacchi, R., Eds.; Accademia Nazionale Dei XL: Roma, Italy, 1995; Volume 14, pp. 335-348.

82. Vialon, P. Etude Géologique du Massif Cristallin Dora-Maira, Alpes Cottiennes Internes, Italie. Géologie Ph.D. Thesis “Thèse d'ètat", Universite'de Grenoble, Grenoble, France, 1966; p. 293. 
83. Henry, C.; Michard, A.; Chopin, C. Geometry and structural evolutionof ultra-high-pressure and high-pressure rocks from the Dora-Maira massif, Western Alps, Italy. J. Struct. Geol. 1993, 15, 965-981. [CrossRef]

84. Sandrone, R.; Cadoppi, P.; Sacchi, R.; Vialon, P. The Dora-Maira Massif. In Pre-Mesozoic Geology in the Alps; Von Raumer, J.F., Neubauer, F., Eds.; Springer: Berlin/Heidelberg, Germany, 1993; pp. 317-325.

85. Compagnoni, R.; Rolfo, F.; Castelli, D. Jadeitite from the Monviso meta-ophiolite, western Alps: Occurrence and genesis. Eur. J. Miner. 2012, 24, 333-343. [CrossRef]

86. Groppo, C.; Ferrando, S.; Gilio, M.; Botta, S.; Nosenzo, F.; Balestro, G.; Festa, A.; Rolfo, F. What's in the sandwich? New P-T constraints for the (U)HP nappe stack of southern Dora-Maira Massif (Western Alps). Eur. J. Miner. 2019, 31, 665-683. [CrossRef]

87. Balestro, G.; Nosenzo, F.; Cadoppi, P.; Fioraso, G.; Groppo, C.; Festa, A. Geology of the southern Dora-Maira Massif: Insights from a sector with mixed ophiolitic and continental rocks (Valmala tectonic unit, Western Alps). J. Maps 2020, 16, 736-744. [CrossRef]

88. Ballèvre, M.; Lagabrielle, Y.; Merle, O. Tertiary ductile normal faulting as a consequence of lithospheric stacking in the western Alps. Mémoire Société Géologique Fr. 1990, 156, 227-236.

89. Tricart, P.; Schwartz, S.; Sue, C.; Lardeaux, J.-M. Evidence of synextension tilting and doming during final exhumation from analysis of multistage faults (Queyras Schistes lustrés, Western Alps). J. Struct. Geol. 2004, 26, 1633-1645. [CrossRef]

90. Guillot, S.; Hattori, K.; Agard, P.; Schwartz, S.; Vidal, O. Exhumation Processes in Oceanic and Continental Subduction Contexts: A Review. In Frontiers in Earth Sciences; Springer Science and Business Media LLC: Berlin/Heidelberg, Germany, 2009 ; pp. 175-205.

91. Tricart, P.; Lemoine, M. The Queyras ophiolite west of Monte Viso (Western Alps): Indicator of a peculiar ocean floor in the Mesozoic Tethys. J. Geodyn. 1991, 13, 163-181. [CrossRef]

92. Schwartz, S.; Lardeaux, J.-M.; Guillot, S.; Tricart, P. Diversité du métamorphisme éclogitique dans le massif ophiolitique du Monviso (Alpes occidentales, Italie) The diversity of eclogitic metamorphism in the Monviso ophiolitic complex, western Alps, Italy. Geodin. Acta 2000, 13, 169-188. [CrossRef]

93. Schwartz, S.; Tricart, P.; Lardeaux, J.M.; Guillot, S.; Vidal, O. Final exhumation of an accretionary wedge (Queyras Schistes Lustrés, Western Alps): Deformation sequence and associated P-T-t path. Geol. Soc. Am. Bull. 2009, 121, 502-518. [CrossRef]

94. Blake, M.C.; Moore, D.E.; Jayko, A.S. The role of serpentinite melanges in the unroofing of ultrahigh-pressure metamorphic rocks: An example from the Western Alps in Italy. In Ultrahigh Pressure Metamorphism; Coleman, R.G., Wang, X., Eds.; Cambridge University Press: Cambridge, UK, 1995; pp. 182-205.

95. Balestro, G.; Fioraso, G.; Lombardo, B. Geological map of the upper Pellice Valley (Italian Western Alps). J. Maps 2011, 7, 634-654. [CrossRef]

96. Angiboust, S.; Langdon, R.; Agard, P.; Waters, D.; Chopin, C. Eclogitization of the Monviso ophiolite (W. Alps) and implications on subduction dynamics. J. Metamorph. Geol. 2012, 30, 37-61. [CrossRef]

97. Philippot, P. Opposite vergence of Nappes and crustal extension in the French-Italian western Alps. Tectonics 1990, 9, 1143-1164. [CrossRef]

98. Lardeaux, J.; Schwartz, S.; Tricart, P.; Paul, A.; Guillot, S.; Béthoux, N.; Masson, F. A crustal-scale cross-section of the south-western Alps combining geophysical and geological imagery. Terra Nova 2006, 18, 412-422. [CrossRef]

99. Groppo, C.; Castelli, D. Prograde P-T evolution of a Lawsonite eclogite from the Monviso Metaophiolite (Western Alps): Dehydration and redox reactions during subduction of oceanic FeTi-oxide gabbro. J. Petrol. 2010, 51, 2489-2514. [CrossRef]

100. Balestro, G.; Lombardo, B.; Vaggelli, G.; Borghi, A.; Festa, A.; Gattiglio, M. Tectonostratigraphy of the northern Monviso Meta-ophiolite Complex (Western Alps). Ital. J. Geosci. 2014, 133, 409-426. [CrossRef]

101. Rubatto, D.; Hermann, J. Zircon formation during fluid circulation in eclogites (Monviso, Western Alps): Implications for Zr and Hf budget in subduction zones. Geochim. Cosmochim. Acta 2003, 67, 2173-2187. [CrossRef]

102. Lombardo, B.; Rubatto, D.; Castelli, D. Ion microprobe U-Pb dating of zircon from a Monviso metaplagiogranite: Implications for the evolution of the Piedmont-Liguria Tethys in the Western Alps. Ofioliti 2002, 27, 109-117.

103. Festa, A.; Balestro, G.; Dilek, Y.; Tartarotti, P. A Jurassic oceanic core complex in the high-pressure Monviso ophiolite (western Alps, NW Italy). Lithosphere 2015, 7, L458.1. [CrossRef]

104. Tartarotti, P.; Caucia, F. Coexisting cummingtonite-sodic amphibole pair in quartzites from the ophiolite's sedimentary cover (St. Marcel Valley, Italian Western Alps): An X-ray structure refinement and petrology study. Neues Jahrb. Mineral. Abh. 1993, 165, 223-243.

105. Tartarotti, P.; Martin, S.; Monopoli, B.; Benciolini, L.; Schiavo, A.; Campana, R.; Vigni, I. Geology of the Saint-Marcel valley metaophiolites (Northwestern Alps, Italy). J. Maps 2017, 13, 707-717. [CrossRef]

106. Tartarotti, P.; Benciolini, L.; Monopoli, B. Brecce serpentinitiche nel massiccio ultrabasico del Monte Avic (falda Ofiolitica Piemontese): Possibili evidenze di erosione sottomarina. Atti Tic. Sc. Terra 1998, 7, 73-86.

107. Tartarotti, P.; Festa, A.; Benciolini, L.; Balestro, G. Record of Jurassic mass transport processes through the orogenic cycle: Understanding chaotic rock units in the high-pressure Zermatt-Saas ophiolite (Western Alps). Lithosphere 2017, 9, $399-407$. [CrossRef]

108. Martin, S.; Rebay, G.; Kienast, J.-R.; Mével, C. An eclogitised oceanic palaeo-hydrothermal field from the St. Marcel Valley (Italian Western Alps). Ofioliti 2008, 33, 49-63.

109. Tumiati, S.; Casartelli, P.; Mambretti, A.; Martin, S.; Frizzo, P.; Rottoli, M. The ancient mine of Servette (Saint-Marcel, Val d'Aosta, Western Italian Alps): A mineralogical, metallurgical and charcoal analysis of furnace slags. Archeometry 2005, 47, 317-340. [CrossRef] 
110. Tumiati, S.; Martin, S.; Godard, G. Hydrothermal origin of manganese in the high-pressure ophiolite metasediments of Praborna ore deposit (Aosta Valley, Western Alps). Eur. J. Miner. 2010, 22, 577-594. [CrossRef]

111. Brown, B.P.; Essene, E.J.; Peacor, D.R. The mineralogy and petrology of Mn-rich rocks from St. Marcel, Piedmont, Italy. Contrib. Mineral. Petrol. 1978, 67, 227-232. [CrossRef]

112. Mottana, A. Blueschist-facies metamorphism of manganiferous cherts: A review of the alpine occurrences. Geol. Soc. Am. Mem. 1986, 164, 267-300. [CrossRef]

113. Nervo, R.; Polino, R. Un lembo di cristallino Dent Blanche alla Torre Ponton (Valle d'Aosta). Boll. Della Soc. Geol. Ital. 1976, 96, 647-657.

114. Bocchio, R.; Benciolini, L.; Martin, S.; Tartarotti, P. Geochemistry of eclogitised Fe-Ti-gabbros from various lithological setting (Aosta valley ophiolites, Italian western Alps). Protolith composition and eclogitic paragenesis. Period. Mineral. 2000, 69, 217-237.

115. Beltrando, M.; Lister, G.; Hermann, J.; Forster, M.; Compagnoni, R.; Hermann, J. Deformation mode switches in the Penninic units of the Urtier Valley (Western Alps): Evidence for a dynamic orogen. J. Struct. Geol. 2008, 30, 194-219. [CrossRef]

116. Ellero, A.; Loprieno, A. Nappe stack of Piemonte-Ligurian units south of Aosta Valley: New evidence from Urtier Valley (Western Alps). Geol. J. 2018, 53, 1665-1684. [CrossRef]

117. Tartarotti, P.; Martin, S.; Meyzen, C.M.; Benciolini, L.; Toffolo, L. Structural Evolution and Metasomatism of Subducted Metaophiolites in the Northwestern Alps. Tectonics 2019, 38, 4185-4206. [CrossRef]

118. Elter, G. Carte géologique de la Vallée d'Aoste, échelle 1:100.000. In Centro Studio sui Problemi dell' Orogeno delle Alpi Occidentali; C.N.R. Torino: Firenze, Italy, 1987.

119. Amstutz, A. Notice puor une carte géologique de la Vallée de Cogne et de quelches autres espaces au Sud d'Aoste. Arch. Sci. Genève 1962, 15, 1-104.

120. Di Colbertaldo, D.; Di Furia, E.; Rossi, F. Il giacimento a magnetite di Cogne in Val d'Aosta. Ist. Lomb. 1967, A101, 361-394.

121. Castello, P. Inventario delle mineralizzazioni a magnetite, ferro-rame e manganese del complesso piemontese dei calcescisti con pietre verdi in Valle d'Aosta. Ofioliti 1981, 6, 5-46.

122. Bethaz, G. Le miniere di Cogne. Rev. Valdotaine d'Hist. Natur. 1987, 41, 149-154.

123. Carbonin, S.; Martin, S.; Tumiati, S.; Rossetti, P. Magnetite from the Cogne serpentinites (Piemonte ophiolite nappe, Italy). Insights into seafloor fluid-rock interaction. Eur. J. Miner. 2015, 27, 31-50. [CrossRef]

124. Toffolo, L.; Nimis, P.; Martin, S.; Tumiati, S.; Bach, W. The Cogne magnetite deposit (Western Alps, Italy): A Late Jurassic seafloor ultramafic-hosted hdrothermal system? Ore Geol. Rev. 2017, 83, 103-126. [CrossRef]

125. Elter, G. Contribution à la connaissance du Briançonnais interne et de la bordur piémontaisedans les Alpes Graies nordorientales et considérations sur les rapports entre les zones dubriançonnais et des schistes lustrés. Mem. Ist. Geol. Min. Univ. Padova 1972, $28,19$.

126. Dal Piaz, G.B. La digitazione gneissica di Val Inferno (Gran Paradiso) e le sue relazioni con la massa frontale del ricoprimento quinto. Rend. Acc. Naz. Lincei 1928, 6, 150-154.

127. Pennacchioni, G. Studio Geologico del Tratto Meridionale Della Dorsale tra Valnontey e Valleile (Cogne, Valle d'Aosta). Mem. Sci. Geol 1988, 40, 333-354.

128. Whitney, D.L.; Evans, B. Abbreviations for names of rock-forming minerals. Am. Mineral. 2010, 95, 185-187. [CrossRef]

129. Le Bayon, B.; Ballèvre, M. Deformation history of a subducted continental crust (Gran Paradiso, Western Alps): Continuing crustal shortening during exhumation. J. Struct. Geol. 2006, 28, 793-815. [CrossRef]

130. Tartarotti, P.; Guerini, S.; Rotondo, F.; Festa, A.; Balestro, G.; Bebout, G.E.; Cannaò, E.; Epstein, G.S.; Scambelluri, M. Superposed Sedimentary and Tectonic Block-In-Matrix Fabrics in a Subducted Serpentinite Mélange (High-Pressure Zermatt Saas Ophiolite, Western Alps). Geoscience 2019, 9, 358. [CrossRef]

131. Rotondo, F.C.; Tartarotti, P.; Guerini, S.; Della Porta, G.; Campomenosi, N. Metasomatic horizon sealing serpentinitemetasediments pair in the Zermatt-Saas metaophiolite (Northwestern Alps): Record of a channel for focussed fluid flow during subduction. Ofioliti 2021, 46, 1-25. [CrossRef]

132. Battiston, P.; Benciolini, L.; Dal Piaz, G.V.; De Vecchi, G.; Marchi, G.; Martin, S.; Polino, R.; Tartarotti, P. Geologia di una traversa dal Gran Paradiso alla Zona Sesia-Lanzo in alta val Soana, Piemonte. Mem. Soc. Geol. It. 1984, 29, $209-232$.

133. Nimis, P.; Omenetto, P.; Stasi, G.; Canovaro, C.; Sasso, G.D.; Artioli, G.; Angelini, I. Lead isotope systematics in ophiolite-associated sulphide deposits from the Western Alps and Northern Apennine (Italy). Eur. J. Miner. 2018, 30, 17-31. [CrossRef]

134. Rolfo, F.; Benna, P.; Cadoppi, P.; Castelli, D.; Favero-Longo, S.E.; Giardino, M.; Balestro, G.; Belluso, E.; Borghi, A.; Cámara, F.; et al The Monviso Massif and the Cottian Alps as Symbols of the Alpine Chain and Geological Heritage in Piemonte, Italy. Geoheritage 2015, 7, 65-84. [CrossRef]

135. Bogatto, S.; Castelli, D. Primary and coronitic to metasomatic mineral assemblages in rodingitic $\mathrm{Mg}$-, $\mathrm{Cr}$ - and Fe-Ti-gabbros from the Monviso ophiolite (Val Varaita, Italian Western Alps). Quad. Geodin. Alp. Quat. 1997, 4, 160-161.

136. Fioraso, G.; Balestro, G.; Festa, A.; Lanteri, L. Role of structural inheritance in the gravitational deformation of the Monviso meta-ophiolite Complex: The Pui-Orgiera serpentinite landslide (Varaita Valley, Western Alps). J. Maps 2019, 15, $372-381$. [CrossRef]

137. Lagabrielle, Y. Ophiolites of the southwestern Alps and the structure of the Tethyan oceanic lithosphere. Ofioliti 1994, 19, 413-434.

138. Principi, G.; Bortolotti, V.; Chiari, M.; Cortesogno, L.; Gaggero, L.; Marcucci, M.; Saccani, E.; Treves, B. The pre-orogenic volcao-sedimentary covers of the Western Tethys oceanic basin: A review. Ofioliti 2004, 29, 177-211. 
139. Lemoine, M.; Marthaler, M.; Caron, M.; Sartori, M.; Amaudric du Chaffaut, S.; Dumont, T.; Escher, A.; Masson, H.; Polino, R.; Tricart, P. Decouverte de foraminifères planctoniques du Crétacé supérieur dans les Schistes lustrés du Queyras (Alpes Occidentales). Conséquences paléogéographiques et tectoniques. C.R. Acad. Sc. Paris 1984, 299, 727-732.

140. Marthaler, M.; Fudral, S.; Deville, E.; Rampnoux, J.-P. Mise en évidence du Crétacé supérieur dans la couverture septentrionale de Dora Maira, région de Suse, Italie (Alpes occidentales). Conséquences paléogéographiques et structurales. C.R. Acad. Sc. Paris 1986, 302, 91-96.

141. Meresse, F.; Lagabrielle, Y.; Malavieille, J.; Ildefonse, B. A fossil Ocean-Continent Transition of the Mesozoic Tethys preserved in the Schistes Lustrés nappe of northern Corsica. Tectonophysics 2012, 579, 4-16. [CrossRef]

142. Reddy, S.; Wheeler, J.; Butler, R.; Cliff, R.; Freeman, S.; Inger, S.; Pickles, C.; Kelley, S. Kinematic reworking and exhumation within the convergent Alpine Orogen. Tectonophysics 2003, 365, 77-102. [CrossRef]

143. Bell, T.H. Deformation partitioning and porphyroblast rotation in meta-morphic rocks: A radical reinterpretation. J. Metamorph. Geol. 1985, 3, 109-118. [CrossRef]

144. Scambelluri, M.; Bebout, G.E.; Belmonte, D.; Gilio, M.; Campomenosi, N.; Collins, N.; Crispini, L. Carbonation of subduction-zone serpentinite (high-pressure ophicarbonate; Ligurian Western Alps) and implications for the deep carbon cycling. Earth Planet. Sci. Lett. 2016, 441, 155-166. [CrossRef]

145. Marroni, M.; Pandolfi, L. The architecture of an incipient oceanic basin: A tentative reconstruction of the Jurassic Liguria-Piemonte basin along the Northern Apennines-Alpine Corsica transect. Acta Diabetol. 2007, 96, 1059-1078. [CrossRef]

146. Marroni, M.; Meneghini, F.; Pandolfi, L. Anatomy of the Ligure-Piemontese subduction system: Evidence from Late Cretaceousmiddle Eocene convergent margin deposits in the Northern Apennines, Italy. Int. Geol. Rev. 2010, 52, 1160-1192. [CrossRef]

147. Tucholke, B.E.; Behn, M.D.; Buck, W.R.; Lin, J. Role of melt supply in oceanic detachment faulting and formation of megamullions. Geology 2008, 36, 455. [CrossRef]

148. Cannat, M.; Sauter, D.; Escartin, J.; Lavier, L.; Picazo, S. Oceanic corrugated surfaces and the strength of the axial lithosphere at slow spreading ridges. Earth Planet. Sci. Lett. 2009, 288, 174-183. [CrossRef]

149. Escartín, J.; Mevel, C.; Petersen, S.; Bonnemains, D.; Cannat, M.; Andreani, M.; Augustin, N.; Bezos, A.; Chavagnac, V.; Choi, Y.; et al. Tectonic structure, evolution, and the nature of oceanic core complexes and their detachment fault zones $\left(13^{\circ} 20^{\prime} \mathrm{N}\right.$ and $13^{\circ} 30^{\prime} \mathrm{N}$, Mid Atlantic Ridge). Geochem. Geophys. Geosyst. 2017, 18, 1451-1482. [CrossRef]

150. Bonatti, E.; Emiliani, C.; Ferrara, G.; Honnorez, J.; Rydell, H. Ultramafic-carbonate breccias from the equatorial Mid Atlantic Ridge. Mar. Geol. 1974, 16, 83-102. [CrossRef]

151. Karson, J.; Lawrence, R. Tectonic setting of serpentinite exposures on the western median valley wall of the MARK area in the vicinity of Site 920. In Proceedings of the Ocean Drilling Program, 153 Scientific Results; International Ocean Discovery Program (IODP), 1997; Volume 153, pp. 5-21. Available online: http://www-odp.tamu.edu/publications/153_SR/VOLUME/ CHAPTERS/sr153_01.pdf (accessed on 5 March 2021).

152. Boillot, G.; Winterer, E.L.; Meyer, A.W. Proceedings of the Ocean Drilling Program, Initial Reports, 103; Ocean Drilling Program: College Station, TX, USA, 1987. [CrossRef]

153. Sawyer, D.S.; Whitmarsh, R.B.; Klaus, A. Proceedings of the Ocean Drilling Program, Initial Reports, 149; Ocean Drilling Program: College Station, TX, USA, 1994. [CrossRef]

154. Whitmarsh, R.B.; Beslier, M.-O.; Wallace, P.J. Proceeding of the Ocean Drilling Program, Initial Reports, 173; Ocean Drilling Program: College Station, TX, USA, 1998. [CrossRef] 